How to cite this work: Escudero Gómez, L.A. (2021). Cultural tourism in cities post-COVID-19: a perspective and proposals for an alternative model. Boletín de la Asociación de Geógrafos Españoles, (91). https://doi.org/10.21138/bage.3138

\title{
Cultural tourism in cities post-COVID-19: a perspective and proposals for an alternative model
}

El turismo cultural urbano tras la pandemia de la COVID-19: una perspectiva y propuestas de un modelo alternativo

\author{
Luis Alfonso Escudero Gómez \\ LuisAlfonso.Escudero@uclm.es \\ Departamento de Geografía y Ordenación del Territorio \\ Universidad de Castilla-La Mancha (Spain)
}

\begin{abstract}
Tourism was a constantly growing industry until the halt brought about by the COVID-19 pandemic. In cities, its negative impact was increasing, with significant cases of overcrowding. COVID-19 has emerged as an exceptional disruptive stage, yet it is also an opportunity to abandon the rush towards unsustainability. This study is a critical analysis of tourism, looking at the most appropriate post-pandemic perspective for urban cultural tourism, based on sustainability and leaving aside the search for profit as the ultimate goal. The main objective is to make proposals for an alternative paradigm. This is a theoretical paper that draws on a literature review of 180 works of scientific reference. Complementarily, information published by the media is accessed and direct observation is carried out as fieldwork. Proposals are made on limiting the number of visitors, improving guided visits, tourist routes, experiential tourism, and virtual tours. We also propose a new centralised tourism governance and regulation of private
\end{abstract}


agents. Therefore, the present text is of interest for public representatives working in the field of urban tourism

Key words: post-COVID-19 tourism; pandemic response; sustainable tourism; tourism policy; crisis management.

\section{Resumen}

El turismo era una máquina en continuo crecimiento hasta su paralización con la pandemia de la COVID-19. En las ciudades, se incrementaban sus impactos negativos y había situaciones de sobreturismo. La pandemia es un momento disruptivo y excepcional. Es una ocasión para abandonar el camino hacia la insostenibilidad. Este artículo es un análisis turístico crítico donde se plantea cuál es la perspectiva pospandémica del turismo cultural urbano con una visión alejada de la búsqueda del lucro como fin último. El objetivo principal es plantear propuestas de un modelo alternativo y sostenible. Es un trabajo teórico que recurre a la revisión literaria de 180 obras científicas. De manera complementaria, se accede a las informaciones de los medios y se realiza una observación de la realidad, con trabajo de campo. Se propone una limitación de los visitantes y una mejora en la calidad mediante visitas guiadas, rutas turísticas, turismo experiencial y turismo virtualizado. Y se plantea una nueva gobernanza turística centralizada y una regulación de los agentes privados. Se considera que el artículo es de interés para los responsables públicos del turismo en las ciudades.

Palabras clave: turismo pos-COVID-19; respuesta pandémica; turismo sostenible; política turística; gestión de crisis.

\section{Introduction}

There is no Chartres or Salisbury feel, with the church as the excuse for everything else (Sinclair, 2015, p. 18).

Normalcy was declared. (Normalcy was always a declaration.) (Roy, 2017, p. 378)

The COVID-19 pandemic is a disruptive event (Baldwin \& Weder, 2020) that has had a great impact on tourism (Pepe \& Percoco, 2020), given the effect on people's movement of nonpharmaceutical interventions, such as the unavoidable experiments with quarantine measures and lockdowns (Florida et al., 2020) or border controls (Ryu et al., 2020), bearing in mind that tourism cannot exist without mobility (Russo, 2016). Sönmez et al. (2019) show that travel networks work as channels for disease proliferation through increased contact caused by rising 
population mobility and can affect tourists that come into contact with pathogens in their destinations, and, similarly, tourism destination residents can be put at risk by exposure to tourists. This has been the pattern in the COVID-19 pandemic, where, indeed, tourism has not only been hit by the consequences but has also been one of the causes (Brito, 2020), having played a key role in its propagation (laquinto, 2020). For this reason, mobility and travel have been restricted. The scale and implications of the current crisis are unparalleled and unprecedented (Corbisiero \& La Rocca, 2020) and tourism is unlikely to continue developing in the same way as before (Castello, 2020).

A report published by the World Tourism Organisation (UNWTO) in January 2020 stated that tourism was a vigorous and robust economic sector (UNWTO, 2020a). Indeed, tourism activity was a continuously growing machine (Mansilla \& Milano, 2018), that, for decades, had been generating constantly rising economic benefits based on increased supply and demand. In fact, this trend could plausibly continue in coming decades and tourism would continue to be a source of income for local and regional economies (Kourtit et al., 2019). Some studies, however, suggest that tourism was sustained by a process where investment was built on the anticipation that visitor numbers would continue to grow indefinitely (Cocola, 2019), but the truth is that, as in many other economic bubbles, such warnings were ignored. However, the COVID-19 pandemic, which started in 2020 and is still growing exponentially in May 2021, obliged tourism flows to be abruptly suspended. Tourism is undoubtedly one of the most seriously affected (Corbisiero \& La Rocca, 2020; Pimentel, 2020) of the major economic sectors (UNWTO, 2020b).

Until a few months ago, cities were developed as tourism destinations under a neoliberal approach (Blanco et al., 2018). Urban spaces specialised in the sector underwent a complete transformation into sites for tourism (Belhassen et al., 2014). City centres were 'touristified' (de la Calle, 2019) with significant negative impacts (Velasco et al., 2019). The intensification of city tourism negatively modified the environmental, economic and social conditions required for future sustainability under any model of development (Blanco et al., 2018). The problems caused by overtourism were exacerbated (Boniface, 2013). Tourism had negative effects on urban destinations, affecting both visitor satisfaction and local residents' quality of life, leading to increasingly serious conflicts (Stecker \& Hartmann, 2019). Concepts such as overtourism (Milano et al., 2019) were the subject of intense academic interest and generated extensive scientific output (Capocchi et al., 2019; Escudero, 2020; Veríssimo et al., 2020). 
Furthermore, having reached the third decade of the 21 st century, the human footprint on the planet is undeniable. The scientific community increasingly uses the neologism 'Anthropocene' to describe the current geologic period. It has become synonymous with the threat to planetary systems posed by human activity (Thomson \& Newman, 2018). Urban tourism is one of the driving forces to blame for the effects of urbanisation on the planet, through its dependence on polluting use of transport -the increase, for example in flights as a result of growing international tourism (Stovall et al., 2019) - and by contributing to worldwide pollution and climate change (Corbisiero \& La Rocca, 2020; Scott et al., 2019). A global approach is needed to respond to planetary limits and sustainable tourism (Hall et al., 2020). Climate change is a major challenge for tourism (Olcina, 2019, 2020) given that its possible future consequences have specific dramatic implications for the activity (Sharpley, 2020). For this reason, robust strategies in tourism are required to fight against climate change (Kietävainen \& Tuulentie, 2013; Prideaux et al., 2020). A number of authors suggest this challenge reflects the need to advance towards a decrease in tourism as an alternative approach to achieve sustainability (Alpestana, 2020; Andriotis, 2018; Mansilla \& Milano, 2018; Sharpley, 2020), as there is ample evidence showing that continuing with a model that prioritises growth is simply unsustainable (Brito, 2020).

Thus, cities' economic dependence on tourism monoculture, the negative impacts of overtourism and the challenge of climate change in the Anthropocene emerged as key problems in urban cultural tourism. The forced halt caused by COVID-19, where the scenario has shifted from overtourism to no tourism (Corbisiero \& La Rocca, 2020), is a unique opportunity to create an alternative model (Ateljevic, 2020; Brouder, 2020; Brito, 2020; Higgins-Desbiolles, 2020; loannides \& Gyimothy, 2020). This exceptional circumstance represents a significant challenge for the global community and, specifically, for the tourism industry (UNWTO, 2020b).

Tourism has demonstrated its resilience, understood as the capacity to recover from a perturbation (Faulkner, 2001; Ritchie, 2008), to rebound from any crisis (Hall et al., 2020). Leveraging this proven resilience, the pandemic represents a historic moment in which to change tourism, where it is possible to propose a new approach (Corbisiero \& La Rocca, 2020), implement a drastic but necessary overhaul (Montanari, 2020) and abandon the path to unsustainability followed by urban cultural destinations. The COVID-19 health crisis should inspire the sustainable relaunch of urban cultural tourism, driving proposals and better decisions for the future and avoiding the repetition of past mistakes (Pepe \& Perococo, 2020). This fork in the road (Brito, 2020) may be an opportunity to tackle the phenomenon of overtourism (Montanari, 2020) in tourist-historic cities (Ashworth \& Tundbridge, 1990). 
COVID-19 has swiftly become a source of academic study in the social sciences (Baldwin \& Weder, 2020; Crítica Urbana, 2020; Finisterra, 2020; Florida et al., 2020; Geopolítica(s), 2020; Harlem \& Lynn, 2020; Reuschke \& Felstead, 2020; Ryu et al., 2020; TeMa, special issue 2020; Zazo \& Álvarez, 2020; Zusman et al., 2020; BAGE, special issue, 2021²). As a sector especially affected by the consequences of the pandemic, works dealing with the issue soon began to appear in the tourism literature (Alpestana, 2020; Ateljevic, 2020; Bakar \& Rosbi, 2020; Bauzá \& Melgosa, 2020; Brito, 2020; Brouder, 2020; Carvalho, 2020; Castello, 2020; Corbisiero \& La Rocca, 2020; Davies, 2020; Fletcher et al., 2020; Flew \& Kirkwood, 2020; Gössling et al., 2020; Gretzel et al., 2020; Guerra, 2020; Hall et al., 2020; Haywood, 2020; Higgins-Desbiolles, 2020; laquinto, 2020; loannides \& Gyimothy, 2020; Jones \& Comfort, 2020; Lapointe, 2020; Menchero, 2020; Montanari, 2020; Murray \& Cañada, 2020; Pascoal et al., 2020; Pepe \& Percoco, 2020; Pimentel, 2020; Prideaux et al., 2020; Sariego, 2020; Sequera, 2020; Simancas et al., 2020; Singh, 2020), and, undoubtedly, the number of studies will continue to rise exponentially.

Rethinking the type of tourism cities should promote is key (Alpestana, 2020; Guerra, 2020). The main aim of the present study is to address this challenge by suggesting approaches and proposals for developing a different type of urban cultural tourism once the COVID-19 pandemic is over. In a world in crisis, studying the effects of the pandemic on urban cultural tourism and designing new proposals are questions that should be urgently addressed. The pressing demands of the present require interrogation, re-exploration and re-envisioning of the future of tourism (Haywood, 2020). Hence, the current study uses an academic perspective to make a critical analysis of tourism in order to pursue responses to the question and propose reflections and proposals for the future, following the example of Haywood (2020). This research primarily focuses on the future of cultural tourism in cities, as did the works by Richards (2019) and McKercher (2020). Nonetheless, where Richards (2019) looks ahead as far as 2095, sketching the future in 75 years' time, and McKercher (2020) presents the main aim of increasing the profitability of cultural tourism by means of new marketing strategies, this article addresses the immediate perspectives of urban cultural tourism in a post-COVID-19 world, based on

1 Special issue: COVID-19 vs CITY-20. Scenarios, insights, reasoning and research (2020). TeMa. Journal of Land Use, Mobility and Environment. http://www.tema.unina.it/index.php/tema/issue/view/510

2 Special issue: Geography against COVID-19. Territorial analysis and multidisciplinary perspectives (2021). Boletín de la Asociación Española de Geografía, (91). https://bage.agegeografia.es/ojs/index.php/bage/issue/view/130 
sustainability (Brito, 2020) in the Anthropocene ( $O^{\prime}$ Callaghan \& Antó, 2020), and removed from the vision of the search for profit as the ultimate goal.

Scientific research can be innovative and propose strategies and operative actions that can support decision-makers (Corbisiero \& La Rocca, 2020). The present is a key moment for public management of tourism and the practical contribution of the current study is to propose an alternative model of urban cultural tourism for policy makers. The challenge of balanced tourism growth is one of the key factors in the General Tourism Plan of any city (García et al., 2017). Nonetheless, there is a lack of general and integrated approaches in tourism management and policies to react to the pandemic (Corbisiero \& La Rocca (2020). The response to the crisis in tourism shows a lack of active decisions for a future sustainable model, and, by contrast, attempts are being made to return to the prior situation while providing economic stimulus packages for the sector (Hall et al., 2020), without actually addressing the challenges and opportunities generated by the pandemic. The intention of this article is to trigger a deeper general debate on post-COVID-19 urban cultural tourism and to incentivise a paradigm shift.

The article continues with a section on the methodology used. This is followed by four sections focused on the principal topics: the limitation of urban cultural tourism after COVID-19, the design of quality tourist visits, centralised tourism management and planning and the commitment to a new approach and proposals for an alternative model. The article finishes with a set of conclusions.

\section{Methodology}

This is a theoretical study, drawing on a number of specific examples, based on the philosophical premise of the need for an alternative, sustainable model of urban cultural tourism after the COVID-19 pandemic. Following Capocchi et al. (2019), it is considered necessary to link theory with practice, not only through case studies, but also by making general proposals that suggest solutions. In addition, in line with D'Auria (2009), this work adopts a creative approach to sustainable development based on urban cultural tourism. The study provides a vision, from the viewpoint of human geography, of the possible changes in tourism paradigms as a result of the pandemic.

The research draws on a literature review of 180 scientific reference works. Complementarily, the information published by the media and online is accessed and direct observation is carried out, 
using fieldwork on the phenomenon under study, that is, urban cultural tourism, from before and after the onset of the pandemic.

As in Hall et al. (2020), the study takes into account the previous literature in the form of a review of a selection of academic studies. Following Bask and Rajahonka (2017), studies were selected and analysed to meet the research aim. Specifically, first, the literature on urban cultural tourism was reviewed, especially that related to the problems generated by overtourism in certain cities. Second, all attempts were made to access the publications emerging in tourism studies on the effects of the pandemic. This involved a continuous search during the research, which was triggered by alerts based on the key words "COVID-19" and "turismo" /"tourism" in Google Scholar and the Scopus databases. As we are dealing with an ongoing phenomenon of great significance, new scientific publications are constantly appearing. All these literature references formed the framework required to develop the introduction and were subsequently the sources used to construct the discussion section.

The literature review was also essential to obtain results. In this case, a thematic search was conducted based on the investigator's main premises. Especially key was obtaining academic articles related to guided visits in urban cultural tourism, the design of tourist routes, experiential tourism and virtualised tourism. These scientific studies lent consistency to the findings. On occasions, use was also made of news in the media and diverse online resources. This was done to seek information on the present and examples for clarification.

The desk research was completed by fieldwork using direct observation. Understanding pre- and post-COVID-19 urban cultural tourism and the search for an alternative model required direct knowledge of the question, which was based on the author's prior experience and fieldwork conducted on visits to Athens and its outskirts, Bilbao (the Guggenheim Museum) and Burgos (the cathedral) during the pandemic in August 2020. These observations served as the source of inspiration for the ideas subsequently developed with the support of the scientific literature and were key to elaborate the discussion section.

The perspectives and proposal presented in this work are built, therefore, on the review of the literature, observation and reflective and analytical deduction with the aims of suggesting purposeful. Despite having an empirical component, the text is essentially conceptual. The intention is to combine the universal and the particular in a dialectic method in which theory and the analysis of specific situations feed off each other, following Benach and Albert (2019) in their comments on the work of David Harvey. 


\section{Limiting urban cultural tourism post-COVID-19 or the end of overtourism and its unsustainable impacts}

To visit Antelope Canyon, in north Arizona, tourists have to form part of a small group that is constantly in the company of a local Navajo guide (Figure 1); free, uncontrolled access is not permitted. Admittedly, it is an example of extremely fragile natural heritage, but future, postCOVID-19 urban cultural tourism must adopt similar measures. That is, the proposal is to limit the number of visitors, and with this, bring an end to overtourism and its negative impacts. Monuments that have implemented similar strategies have shown improvements in sustainability, as reported by Larson and Pudyal (2012) for the case of Machu Picchu, or García (2001) for that of the Alhambra. At destination level, Loades (2019) highlights the example of Dubrovnik, where, in 2017, live surveillance cameras were installed at the five city gates to monitor the numbers entering and leaving through the city wall entrances, as a successful measure to control and manage tourism flows. Limiting the number of visitors to attractions, and even entire destinations, is a solution that works if the steps taken to implement it are reasonable, transparent and fair (Dodds \& Butler, 2019).

The purchase of entrance tickets and tourist packages on the Internet, as has been adopted by multiple cultural tourism sites, is the most equitable environment for visitors to access places with limited availability. Internet has changed the tourism market by altering barriers to entry, minimising switching costs, revolutionising distribution channels, facilitating price transparency and competition, while enhancing production efficiency (Buhalis \& Law, 2008). The idea is to convert from free access to cultural tourism destinations to tourism on demand (Corbisiero \& La Rocca, 2020) with advance sales and limited availability of places.

As heritage sites, cities are complex to manage, but where the growth in tourism flows makes it urgent to design control measures (García, 2000) which, in this disruptive period, in this historic transformative moment (Higgins-Desbiolles, 2020), must be adopted once and for all. To this end, it is essential to place the concept of carrying capacity at the centre of the debate (\#TurismoRESET, 2020), given both its importance in controlling the number of tourist visitors and its usefulness in the challenge generated by COVID-19 of complying with measures of biosafety and maintaining order (Guerra, 2020). The United Nations World Tourism Organisation (UNWTO) defines carrying capacity as "the maximum number of people that may visit a tourist destination at the same time, without causing destruction of the physical, economic, sociocultural environment and an unacceptable decrease in the quality of visitors' satisfaction" (PAP/RAC, 
1997, p. 5). Since the 1970s, the theoretical and practical aspects of the concept have been widely explained in the academic literature (Schneider, 1978; Butler, 1980; Thurot, 1980; O’Reilly, 1986; Williams \& Gill, 1995; García, 2000 \& 2003; McCool \& Lime, 2001; Marsiglio, 2017; Świąder, 2018; Wall, 2020). Most cultural tourism destinations, however, have failed to define their carrying capacity and do not regularly control it, resulting in dramatic tourism overcrowding, as is the case, for example, of Dubrovnik (Stecker \& Hartmann, 2019).

Figure 1. Tourist visits with limited numbers at the Antelope Canyon (Arizona, USA) and the Refectory of the Convent of Santa Maria delle Grazie (Milan, Italy)
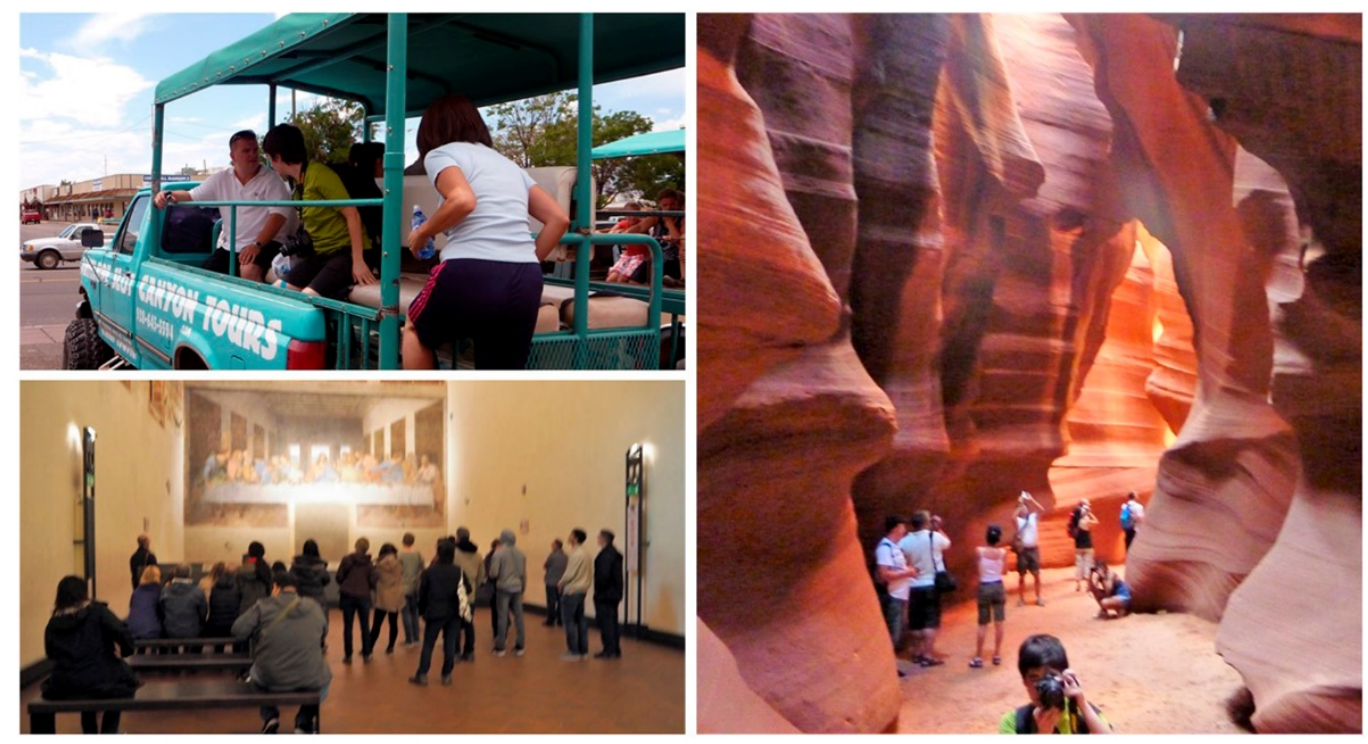

Source: author's own photographs taken on August 4, 2010 (Arizona) and March 30, 2019 (Milan)

It is necessary to construct models linked to carrying capacity to assess sustainability in historic cities (Williams \& Gill, 1995). Technical studies are needed, grounded in reliable data, based on the capacity to receive tourists and which pursue a sustainable equilibrium. Zhang et al. (2015) asked whether urban heritage sites should opt for fully open or limited access for visitors. Due to the effects of COVID-19 -the need, for example, for social distancing between visitors- many heritage tourism sites have been forced to choose the second option: at the Oia Monastery in Galicia (Spain), guided visits are conducted in groups of 24 persons (Vilar, 2020); the Leaning Tower of Pisa reopened on 30 May 2020, with a limit of 15 visitors every 15 minutes (Opera della Primaziale Pisana, 2020), the Royal Alcazar of Seville (Spain) has restricted access to 125 visitors every 30 minutes, while the Alhambra, which, as mentioned, had already limited visitor numbers, has reduced its maximum capacity by half (Kayser, 2020). These options are the result 
of the health crisis, designed to deal with current circumstances, and do not represent voluntary decisions of those who manage such places. For example, the Mosque of Córdoba has increased its capacity in line with the different stages of the de-escalation of the lockdown (Mezquita-Catedral de Córdoba, 2020) and the Louvre has limited its capacity, but expects to increase it as the situation develops with the aim of recovering the maximum possible number of tourists and income (Vicente, 2020).

Wall (2020) proposes possible theoretical solutions to the management of carrying capacity for an entire tourism destination and not just its resources, such as limiting access, restricting activities, imposing participation requirements with permits and licences, enforcing rules and regulations, designating sites for specific activities, increasing control by means of more staff and patrols, varying ease of access, provision of information, education and limiting ancillary facilities, such as parking and accommodation. However, applying such measures across an entire destination is a complex matter, as shown by de la Calle et al. (2021). These authors analyse the use of urban planning regulations as an instrument for containing tourism activity in situations of overtourism in historic centres in Spain and conclude by highlighting imbalances between the economic and urban planning visions, and between the rapid change in tourism and the much slower response capacity of government (de la Calle et al., 2021). During the pandemic, few destinations have applied measures to limit visitor numbers at a scale beyond individual resources. A notable exception, however, is Venice, a city with a serious overtourism problem before the COVID-19 crisis (Bertocchi, 2019), which has decided that, after the pandemic, from summer 2022, admission to the city will be payable, with bookings being made through an application or on the website, using a QR code that will checked by optical readers located at the main points of entry to the historic centre (Gómez, 2021). In contrast, , not only does Athens have no measures to restrict the number of visitors, but it has taken advantage of the forced halt of tourism to increase the visitor capacity when reopening its main attraction, the Acropolis, destroying the access path designed by Dimitris Pikionis (Herreros, 2021).

On occasions, the limits imposed as part of the COVID-19 preventive health measures have even been applied with shortfalls in planning and counterproductive secondary effects. For example, in the National Archaeological Museum of Athens, the standard COVID-19 protocols have been adopted and the number of persons allowed entry is controlled. However, as no advance ticketing system was planned nor is there a clear limit to capacity, people freely access the building and accumulate outside while waiting for a guard to let them enter. Thus, the measures that are to be respected inside the museum are not complied with outside, as the visitors stand 
together with little distance between then and without, in some cases, wearing protective face masks (Figure 2).

Figure 2. Poster announcing COVID-19 health measures and people waiting outside the National Archaeological Museum of Athens
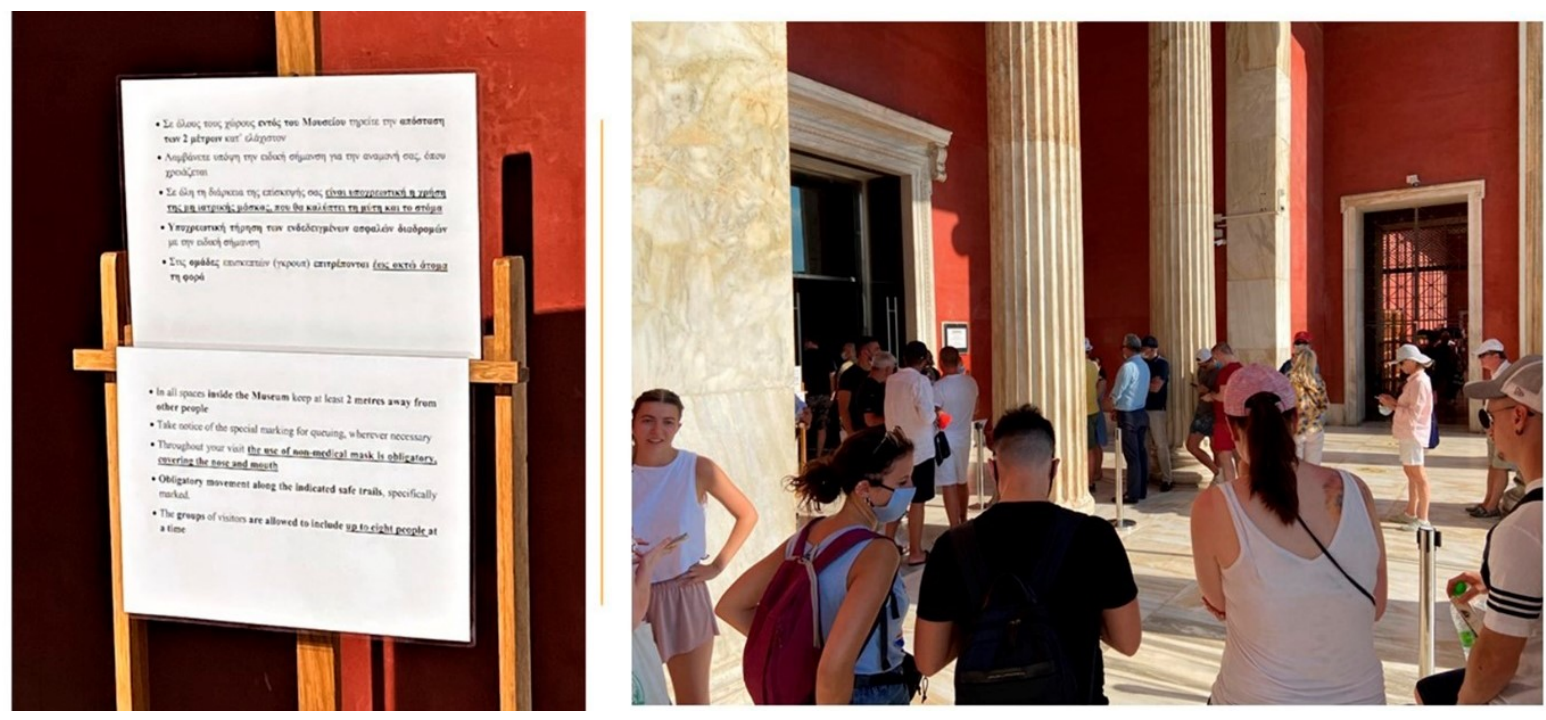

Source: author's own photographs taken on 3 August 2020

Sustainable urban cultural tourism needs well-planned limits to tourist attractions. It is a question of reducing group visits, as in the example of Antelope Canyon, tailoring them to the capacities resulting from calculating the carrying capacity of each site and imposing restrictive policies to achieve it. As proposed by Castello (2020), it is necessary to limit the number of visitors per day at tourist attractions, which would consequently give rise to a fall in the overall number of tourists visiting a city. It is not intended to close cities, but to assume that, if they cannot visit the heritage sites as they do not have tickets, people will not travel to the urban cultural tourism destination.

Moreover, in the first post-COVID-19 phase, it is reasonable to think that the number of those seeking out urban cultural tourism will be lower, as has been corroborated in the fieldwork, either due to the fear of the pandemic that has led to the low tourism demand (Bakar \& Rosbi, 2020), fear of travel as social scarring (Florida et al., 2020) -COVID-19 has left not only an economic after-effects but also social and psychological ones (Guerra, 2020), be it due to the restrictions on mobility caused by the pandemic or the lower level of consumption resulting from the economic crisis triggered by the pandemic. It may also be assumed, as is indeed happening, that the number of flights, especially low-cost ones (Pimentel, 2020), will fall for a time, and, consequently, also the number of international, and even national, tourists. This first reduction, and the disruptive experience of COVID-19, should be capitalised on to raise awareness among 
the population, through education and information, about the necessity of limiting urban cultural tourism.

Additionally, limits to capacity at sports and musical events have been accepted, and thus applying the same process to heritage sites might also be considered appropriate (Dodds \& Butler, 2019). Awareness should be raised among tourists, through education and sensitisation, so they are conscious of the cultural and environmental impacts of excessive, mass tourism on destinations (\#TurismoRESET, 2020). It is important that political decision-makers in tourism focus on the process of educating tourists (Papathanassis, 2017). Tourist can be provided with information and education, which, to be effective, should be carefully coordinated and specifically designed for real problems (Dodds \& Butler, 2019). For example, by means of techniques to promote tourism, it is possible to explain that limits on the number of tourists not only benefit sustainability but also provide visitors with an uncrowded and almost exclusive destination. Such ideas have already been implemented in promoting the reopening of Toledo (La Tribuna de Toledo, 2020), albeit with the sole aim of attracting visitors. Overall, the authorities need to raise awareness of the sustainable development of tourism (Stecker \& Hartmann, 2019).

In short, the aim is to move from theorising a model of sustainable tourism to applying one, where limiting the number of visitors is a guiding principle. Space and time, however, prevent this model being applied in the same way in all cultural tourism destinations. Space, because developing sustainable tourism depends on the initial number of tourists and the state of tourism quality, as reported by Schubert \& Schamel (2020), and time, because the evolution of the pandemic will result in highly diverse scenarios and possibilities in which to apply the novel paradigm. In a scenario without COVID-19, limitations could be applied gradually and in an organised manner, while in the present circumstances, the restrictions are obligated by the pandemic. These are different situations. For example, in a scenario where the pandemic and restrictions on movement are prolonged over time, and, as it seems (Castello, 2020), the current situation is not due to change in the near future, limiting the number of booking or entry tickets to heritage sites in urban destinations, as well as implementing health measures and tests, may be the 'passport' for travel, especially in the case of international movements. It would be necessary to apply an electronic system to authorise journeys, as was obligatory, for example, in the preCOVID world, to visit the United States. Indeed, during the pandemic, to travel between certain countries, it is a requirement to complete a form, either on paper, or preferably online, to obtain a QR (quick response) code. In other cases, it is necessary to be tested for COVID-19 infection before travelling. In this sense, Pimentel (2020) proposes creating an internationally recognised 
Safety and Security tourist card with information on the tourist with regard to infection, immunity or vaccination for COVID-19 and other diseases.

\section{A high-quality tourist visit or the end of mass cultural tourism?}

To visit the 'The Last Supper', Leonardo da Vinci's wall painting, housed in the refectory of the Convent of Santa Maria delle Grazie in Milan, booking is obligatory and access is restricted to a group of 25 people every 15 minutes, a number reduced to 18 due to COVID-19 (Cenacolo Vinciano, 2020). Although it can be visited independently, access is typically as part of a guided group visit. The low number of people compared to the carrying capacity and the pleasure of seeing this masterpiece with the guide's expert explanations make the visit a unique and unforgettable experience, in this author's opinion and that of the travel opinion portal Tripadvisor (2020): "it is worth visiting in small group and the painting can be admired close-up" (Figure 1).

The United Nations Educational, Scientific and Cultural Organisation (UNESCO) recommends cities to develop sustainable tourism practices, including replacing mass tourism with high-quality tourism (UNESCO, 2016). Although, strictly speaking, mass tourism refers simply to large numbers of people and not necessarily bad-quality tourism, empirical evidence in the literature supports an association between the two concepts: mass tourism and a poor visitor experience (Reisinger, 1994; Troitiño \& Troitiño, 2010; Álvarez, 2018; Harrison \& Sharpley, 2017; García et al., 2018; Opačić, 2019; Karamehmedović, 2020; Méndez et al., 2020). Moreover, mass tourism may have multiple negative impacts on urban destinations, which can affect both visitor satisfaction and the quality of life of local residents, which increases the conflict (Stecker \& Hartmann, 2019).

This strategy, with initiatives to encourage a quality tourism offer (Montanari, 2020), undoubtedly involves higher costs for tourists, but the result will be the end of low-price superficial mass tourism, where uninterested demand has resulted in the banalisation of cultural offerings, both material and immaterial (Montanari, 2020), engendering overcrowding and overtourism. Additionally, post- COVID-19 travellers are likely to be willing to pay higher prices (Carvalho, 2020).

The optimum strategy for sustainable tourism is to enhance quality and reduce visitor numbers (Schubert \& Schamel, 2020). Once this number has been limited, the aim would be to fulfil the wishes of tourists to enjoy an uncrowded destination in a quality tourism environment. Due to questions of space, this article will not explore all the possible approaches, but, rather, present 
some proposals that should be applied to urban cultural tourism to improve visit quality. These are explained individually, but are actually intertwined: guided visits, tourist routes, experiential tourism and virtual tourism (Figure 3).

Figure 3. Proposals for post-COVID-19 sustainable urban cultural tourism I

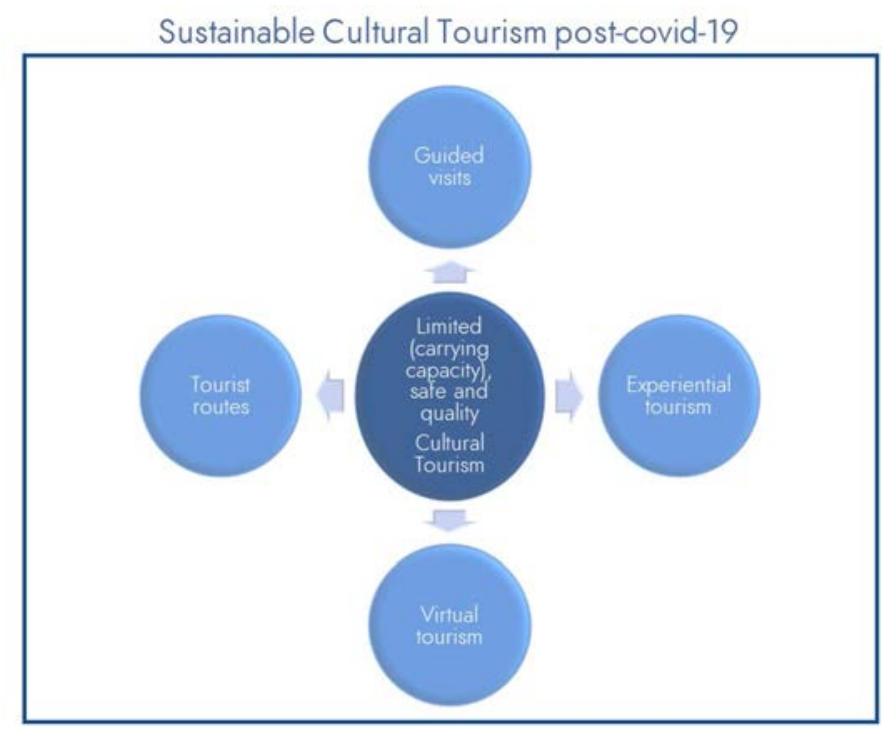

Source: author's own elaboration

\subsection{Guided visits}

Limiting visitor numbers fits perfectly with creating small groups with a tourist guide. In the preCOVID-19 world, visitors using tourist guides were a minority in cultural tourism. In Europe, for example, they were used by only $15 \%$ of visitors (Richards, 2007). Furthermore, guides are one of the tourism industry professions whose employment has been most deeply affected by the health crisis (Crvalho, 2020), being the source of tension and conflict (Riaño, 2020b). Nonetheless, the literature has shown that a visit in the company of an expert guide can provide tourists with a much richer experience (Koo et al., 2019), being one of the factors that influences visitor satisfaction and the intention of returning to the destination (Zhang \& Chow, 2004) and which can be a powerful means of boosting the competitive positioning of the tourism destination (Baker \& Cameron, 2008). Tour guides can play an important role in conserving and adding value to cultural heritage (Santos \& dos Santos, 2019).

Academic research has evidenced a direct relationship between tourist satisfaction and tour guide performance (Ap \& Wong, 2001; Bowie \& Chang, 2005; Chang, 2009; Mak et al., 2011; Huang et al., 2015; Crespí, 2020). The experience of a guided visit tends to generate great satisfaction (Morgan \& Dong, 2008) if guides play an active role (Beattie \& Schneider, 
2018; Crespí-Vallbona, 2020). If not, a visit that involves only observation can be extremely boring and visitors' interest may decline after a few minutes if the guide is unable to capture their interest (Crespí, 2020). Consequently, tour guides hold great responsibility and require good training, especially in heritage sites (Teruel, 2016). Without going too deeply into the question, tour guides require competence in four dimensions: professional competence, interpersonal and organisational skills, problem solving and empathy (Huang et al., 2010). Their activities should be participatory and involve discussion and social interaction during guided visits (Kidd, 2016) -the question of social interaction in tourism experiences is of paramount importance in the motivation, satisfaction and engagement of visitors (Falk \& Dierking, 2012) - and should create an affective dimension among visitors (Crespí, 2020). Their honesty, professionalism and enthusiasm are determining factors of satisfying visits (Huang et al., 2015). In the case of urban cultural tourism, it is also essential for the designers of guided visits to leverage aspects of the local identity, culture and history to differentiate their products and add value (Crespí, 2020). Finally, in light of COVID-19, they must possess the relevant training in hygiene and safety (Carvalho, 2020).

Consequently, it is essential for the discourse and interpretation of the heritage provided by guides, without necessarily being standardised, to be guaranteed and balanced for it to be authentic and accurate, and not based on banalities or falsehoods. Tour guides' work should be continuously appraised. Nonetheless, in Spain, for example, although the tour guide profession has been regulated since the beginning of the 20th century (San Román, 2018), it still presents multiple problems. There is a need for an accreditation system, formal access to positions, appraisals, inspections, rules and regulations, etc. to ensure they perform their job properly.

\subsection{Tourist routes}

One proposal for sustainable post-COVID-19 urban cultural tourism is to design guided tourist routes in cities, which enable visitors to be distributed in a way that is compatible with the destination's carrying capacity and its tourist attractions, with control of the flows, and with the visitors' behaviour within the itineraries and the preventive health measures and safety protocols being those required by the evolution of the pandemic, with the aim of recovering the confidence of the primary source markets and to bolster links with tourists (Sariego, 2020). This safety must be combined with ease of access to the heritage sites, even if this challenge might seem, in principle, more than a little quixotic (Singh, 2020). Additionally, designing high-value 
urban cultural tourist routes would enormously enhance the quality of visits, if this achieves a uniqueness of the tourist product to avoid any form of artificial reproducibility (Montanari, 2020).

Tourist routes are an excellent tool if they are built on a study of the movement patterns of tourists (Xia et al., 2010). They determine useful chronological sequences that help the administrators at the destinations avoid occasional accumulations at specific points in the city and safeguard the social distancing required in times of COVID-19. Using technologies for the management of traffic and flows, similar, for example, to those used in the transport and logistic sectors, and by means of geolocation of groups and contact and communication between guides, it is possible to distribute visitors across the city by proposing specific itineraries. In fact, the use of digital infrastructures to monitor movements and behaviours in urban areas has grown as a means to prevent and fight the pandemic (Alpestana, 2020). These tools can be used to provide real-time information on the state of tourist influx. Moreover, in a post-pandemic future, tourist routs may play a key role in facilitating the management of visitor impacts on the physical environment (Timothy \& Boyd, 2006) and optimising the sequences of visits between the main tourist hubs (Forer \& Pearce, 1984).

Effectively presenting the cultural and historical content of heritage sites requires the design of multiple tourist routes based on different topics (Koo et al., 2019), combining them with experiences, as will be discussed in the next subsection. The literature includes works on the design of routes in specific heritage cities, such as Gerona (Donaire \& Galí, 2008). In urban cultural tourism destinations, in Toledo, for example, the design of tourist routes has been applied to increase the time tourists remain in the city and the number of overnight stays visitors make, and also to add value to their heritage resources (Escudero, 2018); and the pandemic has led to these tours being provided without payment "to reactivate the historic centre" (ABC, 2020). However, the central focus should now be on improving the quality of visits. Furthermore, tourist routes would allow for the promotion of cultural assists and destinations that had fallen into disfavour. These spaces add to the wealth of places to visit and not only help to distribute visitor flows and decongest overcrowded destinations, but also offer a more complete and richer vision of the tourism experience (Martínez et al., 2018). This would serve to take advantage of the opportunity offered by the pandemic to act on the solution suggested by de la Calle (2019) of redirecting tourist flows from highly 'touristified' destinations to other, less crowded competitors.

Routes can be used to create offers at destination that include monuments, complementary activities and the sale of complete, varied experiences (Braintrust, 2018). In this way, tourist 
routes allow approaches to be coordinated with other sectors related to tourism and greatly affected by the crisis, such as the creative arts and the world of culture (Davies, 2020; Flew \& Kirkwood, 2020). The aim would be to hire, offer and integrate ancillary services related to tourism, such as those in the sectors of culture, entertainment and events, respecting the precautions and health measures required while the pandemic persists, following the proposals of Davies (2020).

Furthermore, capitalising on the capacity of culture as a source of differentiation (OECD, 2009), cultural itineraries may be used to create products to sell to specific market segments. This would achieve the aim of creating models of tourism to attract different groups of cultural heritage tourist depending on their motivation (Opačić, 2019). In this sense, it has been shown there are significant differences between the 'specific cultural tourist' and general cultural tourists (McKercher \& du Cros, 2003). Overtourism has been related to the 'uncouth' tourist as opposed to the 'civilised' cultural tourist (Richards, 2019). The focus of tourism development would be shifted towards qualitative growth, seeking to capitalise on market segments with greater value added and a lower impact so as to balance the economic effects of tourism, income and employment with cultural, social and environmental sustainability (Capocchi et al., 2019).

Additionally, the new tourist routes should be integrated with the existing traditional itineraries; the aforementioned city of Toledo, for example, offers many routes, through both private operators and the city council, which designed 12 new routes in 2017. Nonetheless, many of the current routes are exclusively limited to heritage sites whose main function is tourism, as reported by Troitiño (2012) in the case once more of Toledo. Consequently, competitive tenders for tourist routes should be made to find sustainable, high-quality products to attract the public and truly diversify supply. These routes would make up a renewable catalogue, where those that fail to attract visitors are dropped. Constant assessment of results would allow organisers to vary the programme and seek to optimise the supply. Cultural tourism cities would limit the number of visitors but could remain open 24 hours a day, 365 days a year if considered necessary, offering both daytime and night-time routes. Longer timetables would allow for more visitors without increasing overcrowding or squeezing carrying capacities. Furthermore, tourist routes fit perfectly with the typical short trip patterns common in cultural tourism (Ashworth \& Page, 2011), while configuring a broad supply of itineraries might lead tourists to make a second visit or stay for a few days in order to explore all the routes. 
It is essential for routes to eschew a model that concentrates visitors and distributes them spatially across the city using disperse and/or linear resources (Wall, 1997). This would achieve a redistribution of visitors in space and time, which is something frequently called for by theorists in cultural tourism (Alpestana, 2020), but which has not truly been successful, expect perhaps at a very local level (Dodds \& Butler, 2019). Distributing tourist flows is the most promising regulatory form of developing more sustainable cultural tourism in cities (Stecker \& Hartmann, 2019).

Finally, tourist routes would be promoted, booked and paid for online. This is the key moment for culture and heritage to generate appropriate, creative, innovative proposals. Creativity is a potential solution to the problem of homogenisation and serial reproduction of tourist experiences (Richards \& Wilson, 2006).

\subsection{Experiential tourism}

According to the UNWTO, there has emerged a new type of tourist seeking experiences focused on relaxation, discovery, enjoyment and knowledge (UNWTO, 2015). In reality, most tourists simply pursue a holiday experience that is entertaining, pleasant and memorable (Timothy \& Boyd, 2006). In designing tourist routes and urban cultural tourism services in general, to achieve the necessary and much sought creativity and innovation, the offer of experiences is fundamental. Creating experience value in tourism is essential (Prebensen et al., 2014). The postCOVID-19 tourism sector must also take an experiential tourism approach, with the supply gradually shifting from a 'product' to a 'service' and then to an 'experience' (Istoc, 2012). In preCOVID-19 tourism, there was a lack of rich, profound, satisfying experiences (Song \& Tan, 2012). There is a need to change experiences in heritage tourism, which are currently fragmented and superficial, making them more profound, richer and meaningful for tourists (Song \& Tan, 2012). Additionally, it is necessary to develop the possibility of supplying bespoke experiences and to seek authenticity in the supply (Montanari, 2020). Cultural destinations need to create memorable tourism experiences (Jelinčić \& Mansfeld, 2019), as these impact positively on tourists' intention to make return visits and recommend the cultural destination (Chen \& Rahman, 2018).

The combination of tangible and intangible heritage is key in designing the visit. In cultural tourism, travellers appreciate both tangible and intangible elements of culture (Yamashita, 2016) and, as a whole, culture has emerged as one of the primary content providers for tourism experiences (Richards, 2019). It is not only about visiting and interacting in monuments and architectural sites, but also about visiting artisan workshops, learning legends about the city, 
enjoying panoramic views of urban cultural landscapes, trying the local gastronomy, etc. Moreover, cultural tourism attractions should be combined with accommodation, local commerce, restaurants and other tourism services.

Cultural tourism destinations must create more person-to-person interactions, exhibitions and participatory and educational activities that provide experiences for their visitors (Chen \& Rahman, 2018). In short, the idea is to offer a complete experience of the sense of place of a specific tourist destination (Opačić, 2019), to immerse tourists in its culture through more interrelations (Chen \& Rahman, 2018), where guided visits would be the central hub and the tourist routes the connecting path. The aim is to build a sense of enjoyment in urban cultural tourism, understood as the experience of emotions such as inspiration, curiosity and the sensation of being immersed in the historic site and feeling a bond with the location (Kuo et al., 2015). Cultural tourism products designed with a focus on participation, hedonism, knowledge, local culture and nostalgia are the ingredients required to serve up satisfying visits and emotion-filled experiences (Crespí, 2020).

Nonetheless, as mentioned in the case of tourist routes, these experiences must be reasonable proposals. Unrealistic expectations must not be generated among potential visitors so as to avoid their feeling frustrated with the experience and the emotions they feel (Vareiro et al., 2018), while tourists will be satisfied if their perceived experience goes beyond their expectations (Chiu et al., 2016)

\subsection{Virtual tourism}

Immersive technologies, including virtual and augmented reality, have given rise to virtualized reality. Drawing on the power of mixed reality, heritage sites can emerge as places that offer new experimental products for education and entertainment. For example, the new methods of augmented reality can provide a more immersive (Bec et al., 2019) and interactive experience of historical, cultural and architectural details (Koo et al., 2019) and add value to the visitor experience (Jung \& tom Dieck, 2017) and satisfaction (Tsai, 2019). ). Additionally, interactive technologies, which require visitors' active participation, provide opportunities for verbal and physical interaction with others (Ponsignon \& Derbaix, 2020).

Tourism and heritage have been significantly impacted by virtual reality and its potential to facilitate access to cultural sites and resources and to enhance visitors' on-site and off-site experience (Gavalas et al., 2020). Indeed, cultural destinations and attractions have capitalised on augmented and virtual reality to optimise the cultural experience they offer (Richards, 2019). 
Many museums are already using digital technologies to enrich the visiting experience (Siang et al., 2019). The post-COVID-19 future needs to favour digitalization (Sariego, 2020) but, as shown by Hausmann and Schuhbauer (2020) the new technologies, such as augmented reality, continue to be under-used and, to a certain extent, are even little known.

There is a wide range of possibilities in the relationship between cultural tourism and the digital future (Arnold \& Kaminski, 2014). The digital transformation of the management of supply and demand needs to continue to advance (Montanari, 2020). Furthermore, many of the changes subsequent to the pandemic will be driven by new technologies that may usher in an age of cyber-tourism (Corbisiero \& La Rocca, 2020) and virtual tourism, understood as a combination of the real and the virtual, a type of hybrid tourism. Indeed, technical reproductivity can help limit tours and visits by means of total or partial three-dimensional reproductions - as suggested by Choay (2018), although in the form of physical models that can now be produced by virtual reality, thus reducing overcrowding and facilitating social distancing during visits. In this sense, Frey and Briviba (2020) predict that cultural overtourism will return once the pandemic has ended and propose a new conceptual approach they call "Revived Originals", based on identical reproductions of the most visited historic sites in an appropriate location, with the support of the most state-of-the-art digital technology, such as holograms.

Moreover, if we are constantly looking at smartphones in our everyday life and when travelling (Wang et al., 2016), why think they cannot be used while visiting a cultural tourism attraction? This is especially true since we know all tourists carry a mobile phone (Figure 4). Consequently, the use of smartphones in cultural heritage tourism must be carefully considered (Garau, 2014). Experiments have been conducted using smartphones to scan QR codes for virtual assistance in historic buildings (Rodríguez et al., 2013) and at heritage sites in cities such as Naples and Warsaw (Solima \& Izzo, 2019). With COVID-19, this practice has been extended to multiple cases, such as the Cathedral of Burgos and the Guggenheim Museum in Bilbao. The most common use of mobile phones, however, is through applications that incorporate audio guides and information leaflets, as implemented in the city of Toledo (M. G., 2020). Proposals for the future, nonetheless, must be built on more complex theoretical models, such as that suggested by tom Dieck \& Jung (2018) for the use of augmented reality in mobile phones in cultural tourism. Koo et al. (2019) and Siang et al. (2019) developed and implemented an application that does this using the camera scan mode and augmented reality content. 
Other experiments and applications are also in operation, such as the "Beyond the Castle" experience at the Sforzesco Castle in Milan, which recreates historic events from the Renaissance and shows how the castle looked in that age, or the VR Pilgrim application, which allows tourists to combine virtual reality scenes while visiting Christian cultural heritage buildings around the world. In the case of VR Pilgrim, the application is available at the spectacular monasteries in Meteora, in central Greece, declared a UNESCO World Heritage Site. However, its existence is announced with posters and leaflets at some of these monasteries (Figure 4), without, at least during this author's visit, the presence of staff to personally promote the product and supply information on the application. It is of great importance to communicate the specific individual offer of this type of technology and its availability, especially to first-time visitors to a cultural attraction, as they inevitably are less aware of what is on offer and have a greater need for orientation (Hausmann \& Schuhbauer, 2020). Information on an application like VR Pilgrim should not be limited to simply indicating its existence, but its purpose should also be explained and how to use it in the context of the visit and the different stages of the experience. Observations in Meteora suggested that this appealing application was not being used by any of the visitors.

The use of augmented reality in tourism settings is still in its infancy (Siang et al., 2019). Although virtual reality opens up a new and unexplored territory in which to present and disseminate cultural heritage, it continues to represent a challenge (Pybus, 2019). It has, however, enormous potential to make the tourism experience more enjoyable, exciting and interactive (tom Dieck \& Jung, 2018). This qualitative leap requires designing and developing applications that are more accessible and intuitive (Pybus, 2019), with it being crucial to effectively promote, explain and furnish their use among visitors. Smartphones will thus facilitate active learning though visualisation of graphic illustrations that can involve tourists in interactions. The participation of writers and professional voice actors in designing the applications would deliver a creative interpretation and deeply memorable results (Pybus, 2019). This would trigger a symbiotic relationship with the cultural sector, also profoundly damaged by the pandemic, as has been suggested. 
Figure 4. Two visitors referring to their smartphones at the National Archaeological Museum in Athens and poster for the VR Pilgrim app at the Monastery of Saint Nicholas (Meteora, Greece)

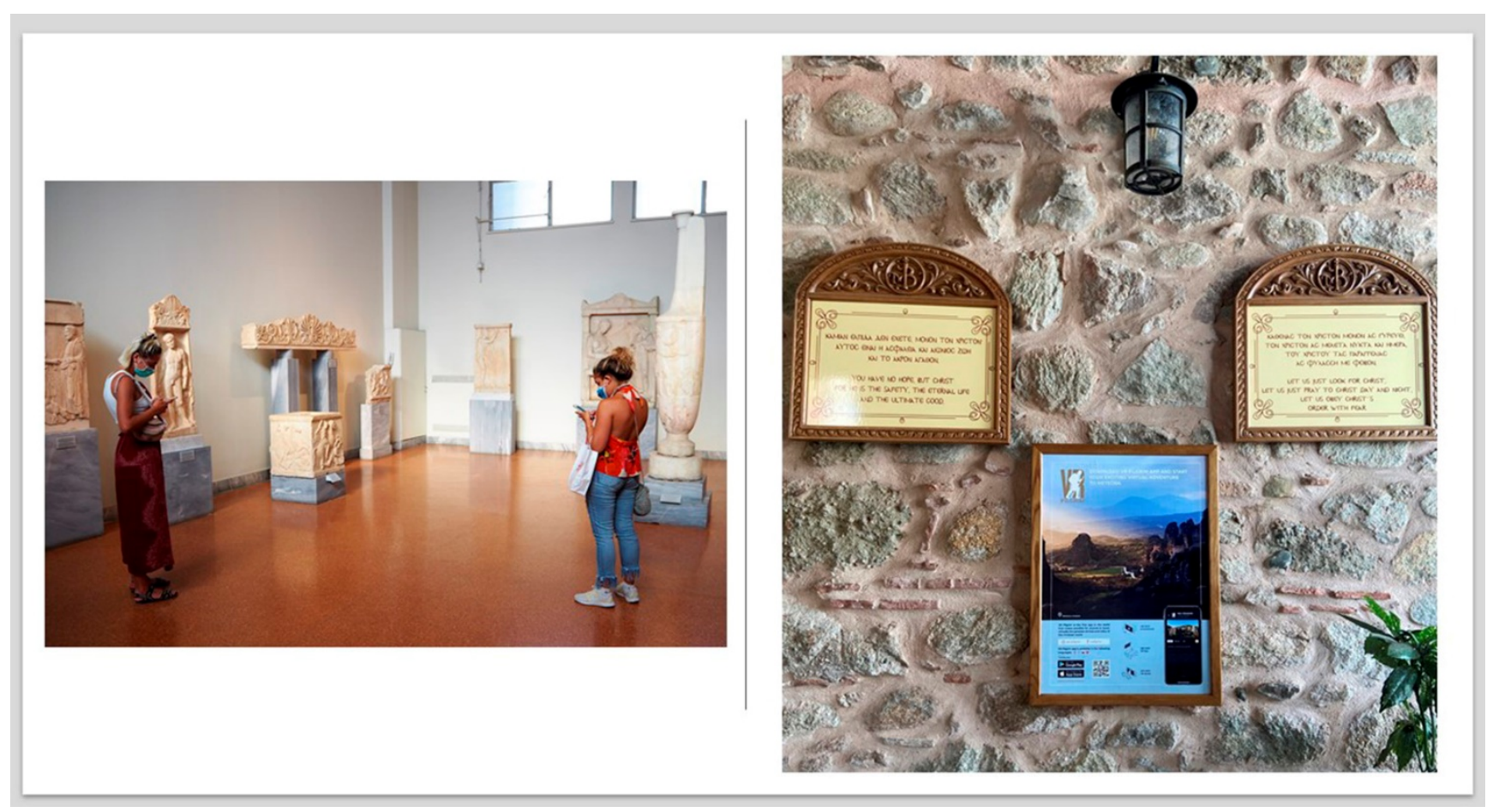

Source: author's own photographs taken on August, 3 \& 5, 2020

The long-term impact of a tourism experience can be significantly increased through the use of technology and social media to maintain contact with visitors once they leave the site (Packer \& Ballantyne, 2016). Tourists use technologies to widely share their experiences and impressions about places they have visited, with a substantial influence on the decision-making processes of others (du Cros \& McKercher, 2002). Social media are critical in promoting cultural tourism destination, being an excellent platform to promote products such as high-quality, guided, experiential tourism routes, which should characterise the cultural tourism of the future. Nonetheless, social media vary in use. A destination opening an account on Facebook, Twitter, Instagram, YouTube, etc., is just the first step, which should be followed by professional management of these networks and others. Strategic management of presence on social media is important (Pascoal et al., 2020).

Finally, the difficulties of movement during the ongoing pandemic and the necessary constraints on the number of visitors to cultural tourism destinations mean, and will continue to mean, that not all the potential tourists will immediately be able to travel to their desired destination and may resort to virtual visits online. As an example, while the Prado Museum in Madrid was closed 
during lockdown, the number of its website visitors rose almost 250\%, exceeding 12 million (Riaño, 2020). In this sense, it is important for the growth in virtual cultural tourism (E-Tourism) to continue, offering quality, plurality and creativity (Gretzel et al., 2020). The availability of online content, be it in the form of archives, live transmission, or the use of virtual reality, is a factor in promoting the destination and a complement to the on-site visit (Alpestana, 2020). The health crisis has forced cultural tourism entities to evolve rapidly, in an arguably excessively improvised and incomplete manner, with the creation or enhancement of virtual visits to multiple attractions (Hooi, 2020). In recent years prior to the pandemic, virtual reality tours had been developed by great cultural heritage institutions, such as the Smithsonian National Museum of Natural History, the Palace of Versailles, the Vatican Museums and the State Hermitage Museum (Marasco, 2020). Cultural tourism post-COVIID-19 must continue to make advances in E-Tourism, developing technologies for web-based support of cultural tourism (Chanchí et al., 2020).

\section{Centralised tourism management and planning and regulation of private tourist agents}

The proposals set out in this article to achieve the sustainability of cultural heritage tourism require a new type of governance of cultural urban tourism based on centralised tourism management and planning, ${ }^{3}$ which includes, as advocated by Hargrove (2017), policies, procedures and guidelines to measure and control impacts and the regulation of private tourist agents. Robust political leadership, governance and the support of residents and visitors are needed (Kuščer \& Mihalič, 2019). Balancing the overall range of interests involved in tourism development is necessarily based on creating an efficient system of governance (Corbisiero \& La Rocca, 2020). The public authorities must ensure heritage sites are preserved, control the number of visitors and inspect tourism services (Feng et al., 2017). The perspectives for urban cultural tourism postCOVID 19 and the measures discussed -for example, regulating and inspecting tourist guides or setting up tourist routes, promoting and selling them-require these functions be bolstered and centralised.

To this end, it is necessary to set up permanent entities representing the tourism sector and local society for public consultations and decision-making (\#TurismoRESET, 2020). These organisations will be tasked with applying policies to manage tourist flows, adapting the technologies required

3 The present study understands centralised tourism governance as a model where the authority, responsibility and the power to make decisions rest exclusively with a central organisation. 
to monitor them -a key aspect to achieve sustainable cultural tourism (Guzmán et al. 2017) and control them (Corbisiero \& La Rocca, 2020), leveraging, for example, the possibilities of smart cities to better manage the tourism flow and physical spaces in cities (Romero et al., 2019). They would also be responsible for the relevant preventive and health measures during the pandemic, as well as for inspecting and following them up. Furthermore, they would administer and implement the previously mentioned tenders for tourist guides and routes.

There have been calls for the setting up of a permanent observatory at heritage sites to constantly monitor the impacts of tourism, introducing preventive and/or corrective measures as and when required (Branton, 2015). However, they exist in few destinations. For example, the World Heritage Cities in Spain lack a permanent, continuous system to collect information from visitors and do not manage data (Braintrust, 2018). The statistics generated in these future observatories should be openly accessible for all administrations, companies, professionals and universities (\#TurismoRESET, 2020). Furthermore, big data analysis management systems on cultural tourism should be established (Cai \& Cai, 2021)

It is worth noting that this new model of tourism governance, with organisations and observatories, the calculation of carrying capacities, setting and control of limits, implementation and management of tourist guides and routes and the designing of experiential and virtual tourism will generate stable employment, with greater use of full-time staff (Hall et al., 2020) receiving appropriate salaries. In contrast to the precarious nature of employment in and through tourism (Cañada, 2019), as demonstrated by the pandemic's impact on employment, with the loss of an enormous number of jobs (Murray \& Cañada, 2020), there emerges the perspective of probably fewer jobs but with better working conditions than those typical of the sector (Lacher $\&$ Oh, 2012).

For urban tourism to function properly, planning and direct governance are required, but are not the definitive solution (Blanco et al., 2018). All stakeholders' opinions must be considered when planning (Dodds \& Butler, 2019). Solutions to sustainability in the tourism system require multilateral responses (Hall et al., 2020). Tourism is a complex system of stakeholders that covers transport services, accommodation, attractions, intermediaries, such as travel agencies and tour operators, and food services, to name just a few (Swanson \& Timothy, 2012). These stakeholders need to be aware that the post-COVID-19 world necessitates a new paradigm, where tourism operators are carefully trained and information is readily available for the new generation of users (Montanari, 2020). Indeed, politicians, the local community and the private tourism system are 
obliged to work together on the measures for tourism resilience (Cheer \& Lew, 2019). Nonetheless, not all the actors in the tourism system regard this opportunity for change as desirable (Hall et al., 2020).

This would be ideal and the foundation on which to implement the new model, but heritage tourism management is, in many senses, a form of conflict resolution (Zhang et al., 2018). If a desirable consensus is not reached, public regulation of tourism services is advocated, with more restrictive rules for tourism-related businesses (Blázquez in Blanchar, 2020) and measures such as limiting the number of accommodation places available.

It is precisely in the area of accommodation where categorical limitations have been implemented by means of modifying urban planning and land use (Arana, 2018). The governmental policy makers can limit the number of tourists that visit a destination by indirect methods such as limiting the number of beds available (Schubert \& Schamel, 2020). Blanco et al. (2018) explain the case of the Tourism Use Plan for the Ciutat Vella in Barcelona related to the regulation and limitation of official hotel accommodation and housing used for tourism.

Figure 5 graphically represents the proposals for governance toward sustainability in post-COVID19 urban cultural tourism.

Figure 5. Proposals for sustainable urban cultural tourism post-COVID-19 ॥

Sustainable Cultural Tourism post-covid-19

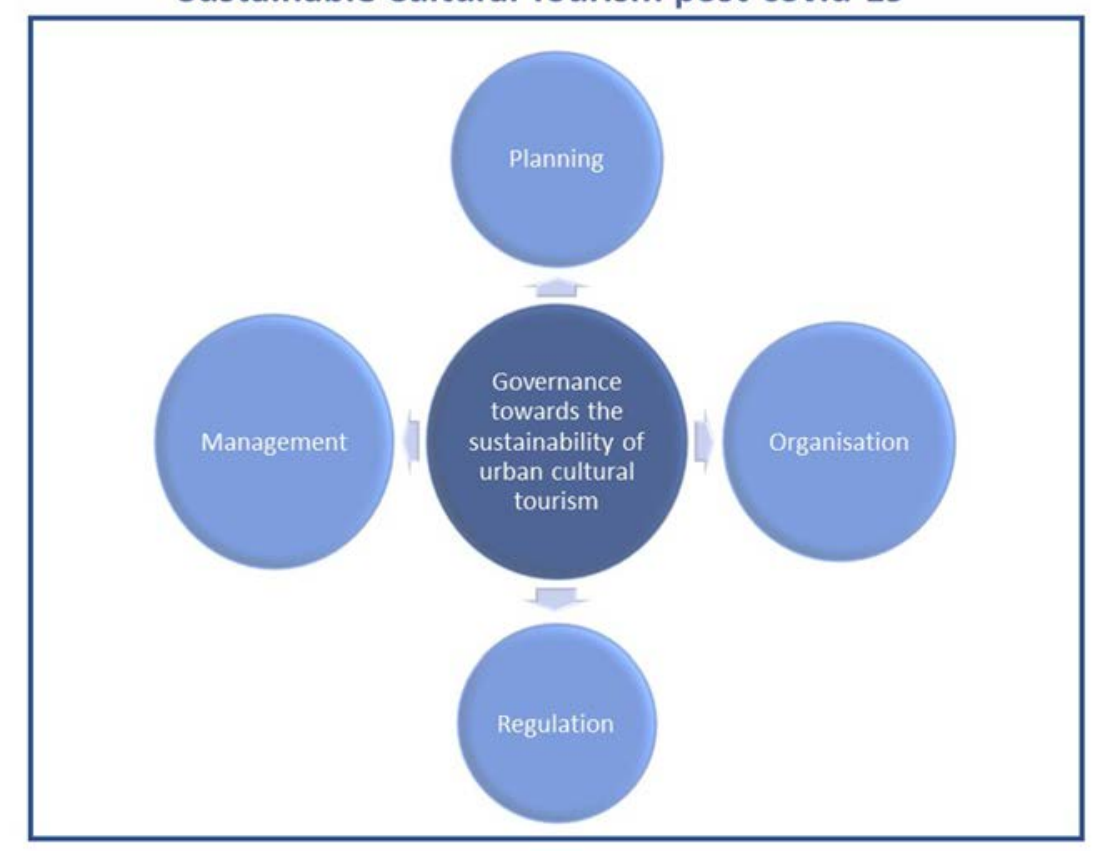

Source: authors' own elaboration 


\section{A new outlook and proposals for an alternative model}

This article, as suggested by Massey (in Albert \& Benach, 2012), has attempted to apply imaginative shock tactics to overhaul antiquated ideas and open the way to new forms of thought. In line with Blanco et al. (2020), the problems of sustainable urban tourism cannot be addressed without radical transformations in the seeking of solutions. Thus, coinciding with Jones \& Comfort (2020), the present study suggests radical solutions to the challenges of tourism sustainability, questioning specifically, as do Corbisiero and La Rocca (2020), the logic that more arrivals mean higher profits and this is what should drive tourism management and planning. This author agrees with Marsigilio (2017), who suggests that public authorities should rethink the policy of attracting increasing numbers of tourists. Although authors such as Haywood (2020) claim that, after the pandemic, traditional economic reactivation should be the priority, this article, in line with Fletcher et al. (2019), defends the application of post-capitalist alternatives and tourism de-growth to resolve the reactivation vs 'touristification' dilemma (Guerra, 2020). This is not, however, a defence of an anti-tourism stance, but, as suggested by Castello (2020), the aim is a planned reduction of tourist flows and concentration that allows for the maximisation of benefits for the local community and the environment. The proposals presented in this article also provide the possibility of greater gains for visitors, who will enjoy higher quality and uncrowded urban cultural tourism.

Some of the proposals made herein conflict with free market capitalism and individual rights, such as freedom of enterprise and the freedom to provide services. Delgadillo (2018) suggests that, in relation to heritage tourism, the State considers its main activities to be the operation of the free market and the reproduction of capital. This article proposes that the administration shift its priorities towards the sustainability of urban cultural tourism. With regard to the freedom of enterprise, the Constitutional Court has ruled that it is not untouchable, and that, if adequately justified, it can be limited and regulated without its foundations being affected (Arana, 2018). For example, in the specific case of hotels and housing used for tourism in Barcelona, a judicial body, the High Court of Justice of Catalonia, ruled that regulating an activity is not equivalent to the impossibility of carrying it out, and thus the right of freedom of enterprise is upheld (Arana, 2018). This is, in effect, a question of politics, and, as stated by Fletcher et al. (2019), repoliticisation of tourism sustainability is needed.

A novel outlook on legislation and power would allow the necessary measures to be taken. COVID-19 has shown that systemic state intervention is possible, to such an extent that the 
population of entire countries can be confined or companies can be obliged to manufacture health products, for example. The pandemic has shown, as noted by Latour (2020), that the world order, which appeared unchangeable, is astonishingly malleable, and that it can be changed by humanity when working as a community. If the existing instruments are substantially modified and new tools are utilised, any policy can be changed and old values can be subverted. This represents a discretional power, which, like any other, as indicated by Arana (2018), must be safeguarded by an exhaustive justification of why the measures are necessary. This author feels that the notion of sustainable urban cultural tourism post-COVID-19 is sufficient guarantee. Public authorities that enable such changes are now essential.

Moreover, if before the pandemic, as stated by Timothy (2011), the economic diversification of tourist cities was important, it is now essential. An end must be put to the monoculture and stagnation of cultural tourism in myriad cities. According to Santos and Lois (2005), tourism in historic cities should never have been configured as the core activity, but rather as part of a pluralistic and multifunctional framework. Tourism should be seen as a complement to other sectors, instead of the primary source of a city's resources, income and employment. It is now time to implement a process to redevelop tourism. If cultural tourism was an economic activity that replaced the industrial employment lost to the economic restructuring initiated in the last 25 years of the 20th century (Richards, 2005), it is now time for other activities to take over and for tourism to be regenerated. As suggested by Yescas (2018), the variations in tourism are a sign of its fragility when facing a disruptive event such as the current pandemic, and thus any governmental interest in supporting the sector to position it as an engine for growth should be questioned. This effort, as stated by Fletcher et al. (2020), will make tourism destination less vulnerable to market fluctuations, caused, for example, by future pandemics.

This article posits a perspective for the future of cultural tourism following the COVID-19 pandemic. Some of the proposals presented have already been implemented in certain destinations, ${ }^{4}$ albeit tentatively and as a result of circumstances, but there lack an outlook and political leadership for the adoption of a new paradigm. Instead, governments' measures have focused on safeguarding financial aspects of the sector and in achieving recovery as broadly and quickly as possible (Hall et al., 2020). Nonetheless, and as stated by Montanari (2020, p. 303):

4 In Burgos, the cathedral, its primary tourist attraction, has limited visitor capacity, designed visitor itineraries, provided QR codes for Smartphone access to explanations, etc. The reader can access a slide show of the author's own photographs of these measures at the following link: https://www.dropbox.com/s/jrne4lbi29hcisr/Presentaci\%C3\%B3n_catedral_Burgos_principal.ppsx?dl=0 
"Tourism offers an important economic and social contribution to Europe's cultural heritage (...), so it is good that it can receive an extraordinary economic support to help it overcome the current crisis. However, it would be detrimental if huge economic contributions were aimed at promoting a return to the mistakes of the recent past".

Tourism destinations are currently making efforts to adapt to COVID-19 health measures (Figure 2) and, particularly, to promote themselves to attract as many visitors as possible. In the case of Spain, where government aid has been made available, many destinations have launched advertising campaigns based on concepts such as proximity, re-opening and safety. ${ }^{5}$ This has been done by the autonomous communities -Andalusia ("Breathe Deeply"), Asturias ("Return to Paradise"), Castilla-La Mancha ("Your holidays have never been so near"), Extremadura ("2021, when we can travel"), Galicia ("Galicia is back"), cities -Córdoba ("The place to meet again"), Málaga ("Better than ever"), Oviedo ("Sure to delight you"), San Sebastián ("Breathe San Sebastián this summer"), Toledo ("Toledo opens up") or Zamora ("A place with life"), and heritage sites -the Guggenheim Museum in Bilbao ("Welcome home") or the Picasso Museum in Málaga ("The genius returns").

Although academic debate reflects serious concern about climate change and the uncertain future of the pre-COVID-19 tourism model, the issue is actually treated with a noticeable lack of depth, when it is essential for tourism to tackle the ecological challenges of our planet (HigginsDesbiolles, 2020). Parts of the business and political communities call for the economy, including tourism, to open up as soon as possible to return to normality, without necessarily considering requirements of sustainability or climate change mitigation (Corbisiero \& La Rocca, 2020; Hall et al., 2020). Moreover, as suggested by Gössling et al. (2020), as soon as the virus is under control, many will feel the urge to compensate for the excessive losses suffered during the pandemic, opting for aggressive growth. Nonetheless, as Montanari (2020) states, going back to normality is not a positive value.

Transforming the tourism system is an extremely complex task (Hall et al., 2020), but the question is whether this is a historic moment in which to reinforce the old tourism paradigms or think of

5 In an advertisement for Vitoria, a couple wearing face masks enjoys a visit to the historic centre: https://www.dropbox.com/s/9onl276mo6uenrs/Vitoria_Gazteiz_publicidad_mascarillas_A\%C3\%91ADIR.png? $\underline{\mathrm{dl}=0}$

6 This museum, a great magnet for tourism, has implemented measures during visits for the COVID-19 pandemic. At the following link, the reader can see a slide show of the author's own photographs: https://www.dropbox.com/s/ox195b/4c1939xz/Presentaci\%C3\%B3n_Guggenheim_principal.ppsx?dl=0 
new ones. The present article prefers the second option and this author believes, as do Corbisiero and La Rocca (2020), that the rebirth of urban cultural tourism requires dramatic changes to the industry and for it to turn its back on the excessive consumption and greed that defined much of the sector before COVID-19. Hall (2011) suggested that the perspective for a new paradigm, with more sustainable forms of tourism, was increasingly unlikely. Cócola's forecast (in Blanchar, 2020) that "once we have the vaccine, everything will go back to normal" is not the ideal scenario for truly sustainable urban cultural tourism in the Anthropocene. As argued by Corbisiero and La Rocca (2020), hopes for a return to pre-COVID-19 patterns of tourism must be questioned if we are to rethink a more sustainable and resilient tourism system and respond to future shocks.

\section{To conclude}

Urban cultural tourism should contribute to an integrated global programme for sustainable development (Istoc, 2012). The COVID-19 pandemic has marked an unprecedented crisis in the sector, but, as argued in the present article, it also represents an opportunity for a new paradigm of sustainability that limits tourism development in cities, respects climate change and one that is, in short, truly sustainable.

The analysis conducted herein defends the need for an alternative, sustainable model for postCOVID-19 urban cultural tourism. The durability and reach of the changes will depend on the timescale of the pandemic (Florida et al., 2020), and on the depth and scope of the recession it has generated (Prideaux et al., 2020). In any event, rethinking a more sustainable and resilient tourism system is essential. In this regard, the present article proposes the perspective of sustainable urban cultural tourism with proposals for limiting tourism and enhancing the quality of visits. Limits on visitor numbers would be established depending on carrying capacities and with the aim of putting an end to overtourism and its negative impacts. Additionally, quality tourist visits should be developed that contrast with the mass tourism model. Guided visits, designing tourist routes, experiential tourism and the possibilities offered by virtualise tourism are the proposals suggested to achieve this aim.

Furthermore, achieving sustainable urban cultural tourism post-COVID-19 urgently requires innovative planning, management and organisation in urban destinations and regulation of the tourism system. The measures proposed necessitate a new form of governance of urban cultural tourism based on centralised tourism management and planning. Permanent public institutions should be set up to take on this task. It is also essential to create tourism observatories with 
experts and technicians for constant supervision of how tourism activity is developed in cities, ready to propose preventive or corrective measures as required.

The proposals put forward in this article are of interest for public policy makers in cities and could enhance the resilience and sustainability of urban cultural tourism, and so halt mass tourism and overtourism if put into practice with respect for the context of each case. The new management models may vary from place to place but should share common policies capable of contributing to the human and cultural growth of cities' residents and visitors (Montanari, 2020). Alternative scenarios have been posited, requiring committed, proactive and optimistic policies. This article presents a theoretical approach that could be the framework for a new paradigm for sustainable urban cultural tourism after COVID-19 and in the Anthropocene, with a rigorous battle against climate change being at the heart of its development. It is a vision of a future where cities are less dependent on tourism, with limits on their exploitation, but with benefits for residents, who will take back their city, for visitors, who will enjoy a more exclusive type of uncrowded, higher-quality urban cultural tourism, and for workers in the sector, who will have better paid, more stable employment.

This article has the logical limitations of being research on perspectives for a future, which is by definition uncertain, and on proposals that admit discussion. The model proposed evidently has constraints and difficulties in the practical implementation of guided visits, tourist routes, experiential tourism and virtual tourism, according to the characteristics of each actual case. Furthermore, the ambition of the article's aims had to be adapted to restrictions of space. The reality of urban cultural tourism is highly complex (actors, urban mobility management, business models, governance, planning (), and it was impossible to address all such as aspects in detail. In this sense, one of the deficiencies is not having delved deeper into the theoretical and conceptual framework, with more extensive references to the definition of urban cultural tourism and the idea of tourism sustainability. Nonetheless, the body of academic literature is sufficiently broad for the reader to seek further information on this theory in other studies (Ashworth \& Page, 2011; Frank \& Medarić, 2018; Sharpley, 2020). Additionally, multiple aspects that have been mentioned should be further developed, discussed in detail and corroborated by case studies. The path has been opened for myriad future works on questions such as the application of carrying capacities and limiting visitor numbers, the role and regulation of tourist guides, the design of tourist routes, the creation of memorable experiences, progress in immersive technologies, tourism governance, etc. For a truly sustainable future, it would be of interest to empirically and practically apply the proposals presented in this research in cultural tourism cities. 
Acknowledgments: This article was developed under the framework of projects RTI2018-096435-B-C22 and RTI2018-093296-B-C22 (MCIU/AEI/FEDER) and SBPLY/19/180501/000184 (JCCM/FEDER). The author would like to thank the anonymous reviews for their careful and exhaustive reading of the manuscript, and their insightful comments and constructive suggestions that have helped improve it. The author is also grateful to the editors of the special thematic issue and of the journal for accepting the research and the publication of the final text.

Authorship statement: The author declares no conflict of interest. 


\section{References}

\#TurismoRESET (2020, May 20). Manifiesto para la regeneración del sector turístico a través de un modelo socialmente equitativo, ambientalmente respetuoso y económicamente sostenible. https://www.turismoreset.org/

ABC (2020, July 27). Toledo ofrece «escape room» y rutas gratis para activar el turismo de lunes a miércoles. ABC. https://www.abc.es/espana/castilla-la-mancha/toledo/ciudad/abci-toledoofrece-escape-room-y-rutas-gratis-para-activar-turismo-lunes-miercoles-202007271402_noticia.html Albert, A., \& Benach, N. (Eds.) (2012). Doreen Massey. Un sentido global del lugar. Icaria.

Alpestana, D. (2020). Os novos desafios do turismo urbano. Finisterra, LV(115), 217221. https://doi.org/10.18055/Finis20342

Álvarez-Sousa, A. (2018). The problems of tourist sustainability in cultural cities: Socio-political perceptions and interests management. Sustainability, 10(2), 503. https://doi.org/10.3390/su10020503

Andriotis, K. (2018). Degrowth in Tourism. Conceptual, Theoretical and Philosophical Issues. CABI. Ap, J., \& Wong, K. (2001). Case study on tour guiding: Professionalism, issues and problems. Tourism Management, 22(5), 551-563. https://doi.org/10.1016/S0261-5177(01)00013-9

Arana García, E. (2018). La intervención local en las viviendas de uso turístico a través de la zonificación urbanística: requisitos y consecuencias. Revista de Estudios de la Administración Local y Autonómica, 10, 6-21. https://doi.org/10.24965/reala.v0i10.10545

Arnold, D., \& Kaminski, J (2014). Cultural heritage tourism and the digital future. In J. Kaminski, A. M. Benson \& D. Arnold (Eds.), Contemporary Issues in Cultural Heritage Tourism (pp. 259282). Routledge.

Ashworth, G. J., \& Tunbridge, J. E. (1990). The Tourist-Historic City. Belhaven Press.

Ashworth, G., \& Page, S. J. (2011). Urban Tourism research: Recent progress and current paradoxes. Tourism Management, 32(1), 1-15. https://doi.org/10.1016/j.tourman.2010.02.002 Ateljevic, I. (2020). Transforming the (tourism) world for good and (re)generating the potential 'new normal'. Tourism Geographies, 22(3), 475. https://doi.org/10.1080/14616688.2020.1759134

Ayuntamiento de Toledo (2017). Vuelta a Toledo en 12 rutas. https://turismo.toledo.es/wpcontent/uploads/2018/01/Nuelta-a-Toledo-en-12-rutas.pdf?x14945 
Bakar, N.A., \& Rosbi, S. (2020). Effect of Coronavirus disease (COVID-19) to tourism industry. International Journal of Advanced Engineering Research and Science, 7(4), 189193. https://doi.org/10.22161/ijaers.74.23

Baker, M. J., \& Cameron, E. (2008). Critical success factors in destination marketing. Tourism and Hospitality Research, 8(2), 79-97. https://doi.org/10.1057/thr.2008.9

Baldwin, R., \& Weder di Mauro, B. (2020). Introduction. In R. Baldwin \& B. Weder di Mauro (Eds.), Economics in the Time of COVID-19 (pp. 1-30). CEPR

Press. https://voxeu.org/system/files/epublication/COVID-19.pdf

Bask, A., \& Rajahonka, M. (2017). The role of environmental sustainability in the freight transport mode choice: a systematic literature review with focus on the EU. International Journal of Physical Distribution \& Logistics Management, 47(7), 560-602. https://doi.org/10.1108/ijpdlm-03-20170127

Bauzá Martorell, F. J., \& Melgosa Arcos, F. J. (Dirs.) (2020). El turismo después de la pandemia global. Análisis, perspectivas y vías de recuperación.

AECIT. https://aecit.org/uploads/public/DOCUMENTO.covid-19\%20y\%20turismo.pdf

Beattie, J. M., \& Schneider, I. E. (2018). Does service type influence satisfaction? A case study of Edinburgh castle. Tourism Management, 67, 97. https://doi.org/10.1016/i.tourman.2018.01.005

Bec, A., Moyle, B., Timms, K., Schaffer, V., Skavroskaya, L., \& Little, C. (2019). Managament of immersive heritage tourism experiences: A conceptual model. Tourism Management, 72, 117120. https://doi.org/10.1016/j.tourman.2018.10.033

Belhassen, Y., Uriely, N., \& Assor, O. (2014). The touristification of a conflict zone: The case of Bil'in. Annals of Tourism Research, 49, 174189. hitps://doi.org/10.1016/i.annals.2014.09.007

Benach, N., \& Albet, A. (2019). David Harvey: diálogo abierto entre la abstracción teórica y la geografía de la urbanización. In N. Benach \& A. Albet (Eds.), David Harvey. La lógica geográfica del capitalismo (pp. 301-336). Icaria.

Bertocchi, D., Camatti, N., Giove, S., \& van der Borg, J. (2020). Venice and Overtourism: Simulating Sustainable Development Scenarios through a Tourism Carrying Capacity Model. Sustainability, 12(2), 512. http://dx.doi.org/10.3390/su12020512

Blanchar, C. (2020, June 16). Los niños reconquistan la Barcelona turística. El País (p. 23). 
Blanco-Romero, A., Blázquez-Salom, M., \& Cànoves, G. (2018). Barcelona, housing rent bubble in a tourist city: Social responses and local policies. Sustainability, 10(6), 2043. https://doi.org/10.3390/su10062043

Boniface, P. (2013). Managing Quality Cultural Tourism. Routledge.

Bowie, D., \& Chang, J. C. (2005). Tourist satisfaction: A view from a mixed international guided package tour. Journal of Vacation Marketing, 11(4), 303322. https://doi.org/10.1177/1356766705056628

Braintrust (2018). Observatorio Turístico del Grupo de Ciudades Patrimonio de la Humanidad de España. http://ciudadespatrimonio.org/publicaciones/GCPHE-Observatorio-Turistico-2018. pdf Branton, J. (2015). World Heritage and Sustainable Tourism: Shared values? In L. Bourdeau, M. Gravari-Barbas, \& M. Robinson (Eds.), World Heritage, Tourism and Identity (pp. 237-256). Ashgate.

Brito-Henriques, E. (2020). COVID-19, turismo e sustentabilidade: tudo está interligado. Finisterra, LV(115), 205-210. https://doi.org/10.18055/Finis20311

Brouder, P. (2020). Reset redux: possible evolutionary pathways towards the transformation of tourism in a COVID-19 world. Tourism Geographies, 22(3), 484490. https://doi.org/10.1080/14616688.2020.1760928

Buhalis, D., \& Law, R. (2008). Progress in information technology and tourism management: 20 years on and 10 years after the Internet-the state of eTourism research. Tourism Management, 29(4), 609-623. https://doi.org/10.1016/j.tourman.2008.01.005

Butler R. W. (1980). The concept of a tourist area cycle of evolution: implications for management of resources. The Canadian Geographer, 24(1), 512. https://doi.org/10.1111/j.1541-0064.1980.tb00970.x

Cai, S.S., \& Cai, S.B. (2020). Big data analysis management system on cultural tourism In Advance in Intelligent Systems and Computing (pp. 504-508). https://doi.org/10.1007/978-3$\underline{030-53980-1+75}$

Calle-Vaquero, M. de la, García-Hernández, M., \& Mendoza de Miguel, S. (2020). Urban Planning Regulations for Tourism in the Context of Overtourism. Applications in Historic Centres. Sustainability, 13(1), 70. http://dx.doi.org/10.3390/su13010070 
Cañada, E. (2019). Trabajo turístico y precariedad. In E. Cañada e I. Murray (Eds.), Turistificación global. Perspectivas críticas en turismo (pp. 267-290). Icaria.

Capocchi, A., Vallone, C., Pierotti, M., \& Amaduzzi, A. (2019). Overtourism: A literature review to assess implications and future perspectives. Sustainability, 11, 3303. https://doi.org/10.3390/su11123303

Carvalho, I. (2020). A profissão de guía-intérprete e o impacto da COVID-19. Journal of Tourism \& Development, 34, 209-222. https://doi.org/10.34624/rtd.v0i34.22414

Castello, V. (2020). Desafíos y oportunidades para el turismo en el marco de la pandemia COVID-19. Cuadernos de Política Exterior Argentina, 131, 115118. https://rephip.unr.edu.ar/handle/2133/18384

Cenacolo Vinciano (2020). Info. https://cenacolovinciano.org/en/info/

Chanchí, G., Saba, M., \& Monroy, M. E. (2020). Propuesta de una arquitectura software basada en realidad virtual para el desarrollo de aplicaciones de turismo cultural. Revista Ibérica de $\begin{array}{lllll}\text { Sistemas e Tenologías } \quad \text { Informação, } & \text { 36, }\end{array}$ 170.

https://search.proquest.com/docview/2462684638?pq-

origsite $=$ gscholar\&fromopenview $=$ true

Chang, J. (2009). Taiwanese tourists' perceptions of service quality on outbound guided package tours: A qualitative examination of the SERVQUAL dimensions. Journal of Vacation Marketing, 15(2), 165-178. https://doi.org/10.1177/1356766708100822

Cheer, J. M., \& Lew, A. A. (2018). Understanding tourism resilience: Adapting to social, political, and economic change. In J. M. Cheer \& A. A. Lew (Eds.), Routledge Advances in Tourism: Vol. 42. Tourism, Resilience and Sustainability: Adapting to Social, Political and Economic Change (pp. 3-17). Routledge.

Chen, H., \& Rahman, I. (2018). Cultural tourism: An analysis of engagement, cultural contact, memorable tourism experience and destination loyalty. Tourism Management Perspectives, 26, 153-163. https://doi.org/10.1016/j.tmp.2017.10.006

Chiu, W., Zeng, S., \& Cheng, P. (2016). The influence of destination image and tourist satisfaction on tourist loyalty: A case study of Chinese tourists in Korea. International Journal of Culture, Tourism and Hospitality Research, 10(2), 223-234. https://doi.org/10.1108/IJCTHR-07$\underline{2015-0080}$

Choay, F. (2018) [1992]. Alegoría del patrimonio (Trans. By Mª. Suazo). Gustavo Gili. 
Cocola-Gant, A. (2019). Gentrificación turística. In E. Cañada \& I. Murray (Eds.), Turistificación global. Perspectivas críticas en turismo (pp. 291-308). Icaria.

Corbisiero, F., \& La Rocca, R. A. (2020). Tourism on demand. A new form of urban and social demand of use after the pandemic event. TeMa. Journal of Land Use, Mobility, and Environment, 91-104. http://dx.doi.org/10.6092/1970-9870/6916

Crespí-Vallbona, M. (2020). Satisfying experiences: Guided tours at cultural heritage sites. Journal of Heritage Tourism, 16(2), 201-17. https://doi.org/10.1080/1743873X.2020.1771345

Crítica Urbana (2020). Coronavirus: impacto urbano y territorial. 15, 1 52. hittps://criticaurbana.com/wp-content/uploads/2020/11/Cr\%C3\%ADtica-Urbana$\underline{15 \_ \text {Completa.pdf }}$

D'Auria, A. (2009). Urban cultural tourism: Creative approaches for heritage-based sustainable development. International Journal of Sustainable Development, 12(2/3/4). 275 289. https://doi.org/10.1504/ijsd.2009.032782

Davies, K. (2020). Festivals Post Covid-19. Leisure Sciences, 43(1-2), 184189. https://doi.org/10.1080/01490400.2020.1774000

de la Calle Vaquero, M. (2019). Turistificación de centros urbanos: clarificando el debate. Boletín de la Asociación de Geógrafos Españoles, 83, 2829. https://doi.org/10.21138/bage.2829

Delgadillo, V. (2018). Turismo y patrimonio. Cincuenta años de «rescate» del Centro Histórico de la Ciudad de México. Estudios Críticos del Desarrollo, VIII(14), 141 170. https://www.academia.edu/39133022/Turismo_y_patrimonio_Cincuenta_a\%C3\%B1os_de rescate_del_Centro_Hist\%C3\%B3rico_de_la_Ciudad_de_M\%C3\%A9xico

Dodds, R., \& Butler, R.W. (2019). Conclusion. In R. Dodds \& R. W. Butler (Eds.), Overtourism. Issues, Realities and Solutions (pp. 262-276). De Gruyter.

Donaire Benito, J.A., \& Galí Espelt, N. (2008). Modeling tourist itineraries in heritage cities. Routes around the Old District of Girona. Pasos. Revista de Turismo y Patrimonio Cultural, 6(3), 435-449. https://doi.org/10.25145/j.pasos.2008.06.033

du Cros, H., \& McKercher, B. (2002). Cultural Tourism. The Partnership between Tourism and Cultural Heritage Management $\left(2^{\text {nd }}\right.$ ed.). Routledge. 
Escudero Gómez, L. A. (2018). Realities and problems of a major cultural tourist destination in Spain, Toledo. Pasos. Revista de Turismo y Patrimonio Cultural, 16(3), 617636. https://doi.org/10.25145/j.pasos.2018.16.045

Escudero Gómez, L. A. (2020). Perceptions and opinions of the host community regarding overtourism in the touristic-historic city: A case study in Toledo (Spain). In C. Ribeiro de Almeida, et al. (Eds.), Handbook of Research on the Impacts, Challenges, and Policy Responses to Overtourism (pp. 325-345). IGI Global.

Falk, J. H., \& Dierking, L. D. (2012). The Museum Experience Revisited. Routledge.

Faulkner, B. (2001). Towards a framework for tourism disaster management. Tourism Management, 22(2), 135-147. https://doi.org/10.1016/S0261-5177(00)00048-0

Feng, J., Li, Y., \& Wu, P. (2017). Conflicting images of the Great Wall in cultural heritage tourism. Critical Arts, 37(6), 109-127. https://doi.org/10.1080/02560046.2017.1405455

Finisterra (2020). Número especial: COVID-19, 55(115). https://revistas.rcaap.pt/finisterra

Fletcher, R., Murray Mas, I., Blanco Romero, A., \& Blázquez Salom, M. (2019). Tourism and degrowth: An emerging for research and praxis. Journal of Sustainable Tourism, 27(12). 17451763. https://doi.org/10.1080/09669582.2019.1679822

Fletcher, R., Murray, I., Blázquez, M., \& Blanco, A. (2020, 24 de marzo). Turismo, $\begin{array}{llllll}\text { decrecimiento } & \text { y } & \text { la crisis del } & \text { COVID-19. }\end{array}$ Sud. http://www.albasud.org/blog/es/1196/turismo-decrecimiento-y-la-crisis-del-covid-19

Flew, T., \& Kirkwood, K. (2020). The impact of COVID-19 on cultural tourism: Art, culture and communication in four regional sites of Queensland, Australia. Media International Australia, 178(1), 16-20. https://doi.org/10.1177/1329878X20952529

Florida, R., Rodríguez-Pose, A., \& Storper, M. (2020). Cities in a Post-COVID World. Papers in Evolutionary Economic Geography, 20.41. http://econ.geo.uu.nl/peeg/peeg2041.pdf

Forer, P. C., \& Pearce, D. G. (1984). Spatial patterns of package tourism in New Zealand. New Zealand Geographer, 40(1), 34-43.

Frank, T. O., \& Medarić, Z. (2018). Cultural tourism from an academic perspective. Academica Turistica, 11(2), 101-110. http://academica.turistica.si/index.php/AT-TIJ/article/view/141 
Frey, B. S., \& Briviba, A. (2020). Revived Originals - A proposal to deal with cultural overtourism. Tourism Economics, 27(6), $1221-$

1236. https://doi.org/10.1177/1354816620945407

Garau, C. (2014). From territory to smartphone: Smart fruiton of cultural heritage for dynamic tourism development. Planning Practice \& Research, 29(3), 238255. https://doi.org/10.1080/02697459.2014.929837

García, J. A., Guitart Casalderrey, N., Pitarch Mach, A., \& Vallvé Fernández, O. (2018). De la turismofobia a la convivencia turística: el caso de Barcelona. Análisis comparativo con Ámsterdam y Berlín. Ara: Revista de Investigación en Turismo, 8(2), 25-34.

García Hernández, M. (2000). Turismo y medio ambiente en ciudades históricas. De la capacidad de acogida turística a la gestión de los flujos de visitantes. Anales de Geografía de la Universidad Complutense, 20, 131-148.

https://revistas.ucm.es/index.php/AGUC/article/view/AGUC0000110131A

García Hernández, M. (2001). Capacidad de acogida turística y gestión de flujos de visitantes en conjuntos monumentales: el caso de la Alhambra. PH, Boletín del Instituto Andaluz del Patrimonio Histórico, 36, 124-137. https://www.ucm.es/data/cont/media/www/pag49172/ph36-124\%20(publicaci\%C3\%B3n).pdf

García Hernández, M. (2003). Turismo y conjuntos monumentales. Capacidad de acogida turística y gestión de flujos de visitantes. Tirant Lo Blanc.

García Hernández, M., de la Calle Vaquero, M., \& Yubero, C. (2017). Cultural heritage and urban tourism: Historic city centres under pressure. Sustainability, 9(8), 1346. hitps://doi.org/10.3390/su9081346

Gavalas, D., Sylaiou, S., Kasapakis, V., \& Dzardanova, E. (2020). Special issue on virtual and mixed reality in culture and heritage. Personal and Ubiquitous Computing, 12. https://doi.org/10.1007/s00779-020-01377-4

Geopolítica(s) (2020). Número Extraordinario dedicado a Geopolítica de la pandemia de COVID-19, 11(2), 1-321. https://revistas.ucm.es/index.php/GEOP/issue/view/3602

Gómez Fuentes, A. (2021, August 24). Para entrar en Venecia habrá que reservar y pagar a partir del próximo verano. ABC. https://www.abc.es/cultura/abci-para-entrar-venecia-habrareservar-y-pagar-partir-proximo-verano-202108231642_noticia.html 
Gössling, S., Scott, D., \& Hall, C. M. (2020). Pandemics, tourism and global change: A rapid assessment of COVID-19. Journal of Sustainable Tourism, 29(1), 120. https://doi.org/10.1080/09669582.2020.1758708

Gretzel, U., Fuchs, M., Baggio, R., Hoepken, W., Law, R., Neidhardt, J., Pesonen, J., Zanker, M., \& Xiang, Z. (2020). E-Tourism beyond COVID 19: A call for transformative research. Information Technology \& Tourism. Information Technology \& Tourism, 22, 187203. https://doi.org/10.1007/s40558-020-00181-3

Guerra Luzuriaga, P. (2020). Reactivación vs turistificación: los retos de las ciudades frente al turismo post pandemia. INNOVA Research Journal, 5(3.2.), 134150. https://doi.org/10.33890/innova.v5.n3.2.2020.1564

Guzmán, P.C., Pereira Roders, A.R., \& Colenbrander, B.J.F. (2017). Measuring links between cultural and heritage management and sustainable urban development: An overview of global monitoring tools. Cities, 60, 192-201. https://doi.org/10.1016/j.cities.2016.09.005

Hall, C.M. (2011). Policy learning and policy failure in sustainable tourism governance: From firstand second-order to third-order change? Journal of Sustainable Tourism, 19(4-5), 649671. https://doi.org/10.1080/09669582.2011.555555

Hall, C. M., Scott, D., \& Gössling, S. (2020): Pandemics, transformations and tourism: Be careful what you wish for. Tourism Geographies. https://doi.org/10.1080/14616688.2020.1759131 Hargrove, C.M. (2017). Cultural Heritage Tourism: Five Steps for Success and Sustainability. Rowman \& Littlefield.

Harlem, G., \& Lynn, M. (2020). Descriptive analysis of social determinant factors in urban communities affected by COVID-19. Journal of Public Health, fdaa078. https://doi.org/10.1093/pubmed/fdaa078

Harrison, D., \& Sharpley R. (2017). Mass Tourism in a Small World. CABI.

Hausmann, A., \& Schuhbauer, S. (2020). The role of information and communication technologies in cultural tourists' journeys: the case of a World Heritage Site. Journal of Heritage Tourism. https://doi.org/10.1080/1743873X.2020.1819300

Haywood, K.M. (2020). A post-COVID future: Tourism community re-imagined and enabled. Tourism Geographies, 22(3), 599-609. https://doi.org/10.1080/14616688.2020.1762120

Herreros, J. (2021, May 30). Intro. El País Semanal (p. 16). 
Higgins-Desbiolles, F. (2020). Socialising tourism for social and ecological justice after COVID19. Tourism Geographies, 22(3), 610-623. https://doi.org/10.1080/14616688.2020.1757748 Hooi, A. (2020, June 25). Conocer la Ruta de la Seda sin moverse de casa. El País-China Daily (p. 7).

Huang, S., Hsu, C. H. C., \& Chan, A. (2010). Tour guide performance and tourist satisfaction: A study of the package tours in Shanghai. Journal of Hospitality \& Tourism Research, 34(1), 333. https://doi.org/10.1177/109634800934981

Huang, S., Weiler, B., \& Assaker, G. (2015). Effects of interpretive guiding outcomes on tourist satisfaction and behavioral intention. Journal of Travel Research, 54(3), 344358. https://doi.org/10.1177/0047287513517426

laquinto, B. L. (2020). Tourist as vector: viral mobilities of COVID-19. Dialogues in Human Geography, 10(2), 174-177. https://doi.org/10.1177/2043820620934250

loannides, D., \& Gyimothy, S. (2020). The COVID-19 crisis as an opportunity for escaping the unsustainable global tourism path. Tourism Geographies, 22(3), 624632. https://doi.org/10.1080/14616688.2020.1763445

Istoc, E.M. (2012). Urban culture tourism and sustainable development. International Journal for Responsible Tourism, 1(1), 38-56. https://ideas.repec.org/a/amf/ijrtfa/v1y2012i1p38-57.html

Jelinčić, D. A., \& Mansfeld, Y. (2019). Applying cultural tourism in the revitalization and enhancement of cultural heritage: An integrative approach. In M. Obad Šćitaroci, B. B. Obad Šćitaroci \& A. Mrđa (Eds.), Cultural Urban Heritage. Development, Learning and Landscape Strategies (pp. 35-43). Springer.

Jones, P., \& Comfort, D. (2020). The COVID-19 crisis, tourism and sustainable development. Athens Journal of Tourism, 7(2), 75-86. https://doi.org/10.30958/ajt.7-2-1

Jung, T. H., \& tom Dieck, C. (2017). Augmented reality, virtual reality and 3D printing for the cocreation of value for the visitor experience at cultural heritage places. Journal of Place Management and Development, 10(2), 140-151. https://doi.org/10.1108/JPMD-07-2016-0045

Karamehmedović, D. (2020). The spirit of the place. Visitor study on Dubrovnik. In K. Luger T M. Ripp (Eds.), World Heritage, Place Making and Sustainable Tourism (pp. 269-286). Studien Verlag.

Kayser, B. (2020, June 19). Cómo será volver al El Viajero-El País (p. 8). 
Kidd, J. (2016). Museums in the New Mediascape: Transmedia, Participation, Ethics. Routledge.

Kietäväinen, A., \& Tuulentie, S. (2013). Tourism strategies and climate change: Rhetoric at both strategic and grassroots levels about growth and sustainable development in Finland. Journal of Sustainable Tourism, 21(6), 845-861. https://doi.org/10.1080/09669582.2012.750326

Koo, S., Kim, J., Kim, C., Kim, J., \& Cha, H. S. (2019). Development of an augmented reality tour guide for a cultural heritage site. ACM Journal on Computing and Cultural Heritage, 12(4), 24. https://doi.org/10.1145/3317552

Kourtit, K., Nijkamp, P., \& Romão, J. (2019). Cultural heritage appraisal by visitors to global cities: The use of social media and urban analytics in urban buzz research. Sustainability, 11(12), 3470. https://doi.org/10.3390/su11123470

Kuo, N. T., Chang, K. C., Cheng, Y. S., \& Lin, J. C. (2015). Effects of tour guide and tourist satisfaction on destination loyalty in Taiwan's Kinmen battlefield tourism: Perceived playfulness and perceived flow as moderators. Journal of Travel \& Tourism Marketing, 33(1), 103122. https://doi.org/10.1080/10548408.2015.1008670

Kuščer, K., \& Mihalič, T. (2019). Residents' attitudes towards overtourism from the perspective of tourism impacts and cooperation-the case of Ljubljana. Sustainability, 11, 1823. https://doi.org/10.3390/su11061823

La Tribuna de Toledo (2020, July 7). Toledo inicia una campaña de promoción turística. La Tribuna de Toledo. hittps://www.latribunadetoledo.es/noticia/Z721486E9-A201-4FFO833235612E3029B1/202007/Toledo-inicia-una-campana-de-promocion-turistica

Lacher, R. G., \& Oh, C. (2012). Is tourism a low-income industry? Evidence from three coastal regions. Journal of Travel Research, 51(4), 464472. https://doi.org/10.1177/0047287511426342

Lapointe, D. (2020). Reconnecting tourism after COVID-19: The paradox of alterity in tourism areas. Tourism Geographies, 22(3), $633-$ 638. https://doi.org/10.1080/14616688.2020.1762115

Larson, L., \& Poudyal, N. (2012). Developing sustainable tourism through adaptive resource management: a case of study in Machu Picchu, Peru. Journal of Sustainable Tourism, 20(7), 917938. https://doi.org/10.1080/09669582.2012.667217 
Latour, B. (2020, May 4). Plasticidad en el orden mundial. El País. https://elpais.com/especiales/2020/coronavirus-covid-19/predicciones/la-plasticidaddel-orden-mundial/

Loades, C. M. (2019). Heritage and scale-challenges to wellbeing and place management in Dubrovnik's World Heritage Site. Journal of Culture Research, 19, 532. https://doi.org/10.14456/jucr.2019.7

M. G. (2020, June 25). La Iglesia abre mañana la Catedral y otros monumentos. La Tribuna de Toledo. https://www.latribunadetoledo.es/Noticia/Z39488C47-C76D-5D05A55DD0565DA9342A/202006/La-lglesia-abre-manana-la-Catedral-y-otros-monumentos

Mak, A.H.N., Wong, K.K.F., \& Chang, R.C.Y. (2011). Critical issues affecting the service quality and professionalism of the tour guides in Hong Kong and Macau. Tourism Management, 32(6), 1442-1452. https://doi.org/10.1016/j.tourman.2011.01.003

Mansilla, J.A., \& Milano, C. (2018). Introducción a la Ciudad de Vacaciones. Apuntes sobre turismo y malestar social en Barcelona. In C. Milano \& J.A. Mansilla (Coords.), Ciudad de Vacaciones. Conflictos urbanos en espacios turísticos (pp. 19-80). Pol.len.

Marasco, A. (2020). Beyond virtual cultural tourism: History-living experiences with cinematic virtual reality. Tourism \& Heritage Journal, 2, 116. https://revistes.ub.edu/index.php/tourismheritage/article/view/31349

Marsiglio, S. (2017). On the carrying capacity and the optimal number of visitors in tourism destinations. Tourism Economics, 23(3), 632-646. https://doi.org/10.5367/te.2015.0535

Martínez García, E., Raya Vílchez, J. M., \& Galí, N. (2018). Factors affecting time spent visiting heritage city areas. Sustainability, 10, 1824. https://doi.org/10.3390/su10061824

McCool, S. F., \& Lime, D. W. (2001). Tourism carrying capacity: Tempting fantasy or useful reality. Journal of Sustainable Tourism, 372388. https://doi.org/10.1080/09669580108667409

McKercher, B. (2020). Cultural tourism market: A perspective paper. Tourism Review, 75(1), 126129. https://doi.org/10.1108/TR-03-2019-0096

McKercher, B., \& du Cros, H. (2003). Testing a cultural tourism typology. International Journal of Tourism Research, 5(1), 45-58. https://doi.org/10.1002/jtr.417 
Menchero Sánchez, M. (2020). Flujos turísticos, geopolítica y COVID-19: cuando los turistas internacionales son vectores de transmisión. Geopolítica(s), 11(2), 105 114. https://doi.org/10.5209/geop.69249

Méndez Ravina, L. M., Aviña Solares, M. G. A., \& Solís Martínez, H. (2020). Tourism in Mexico and the use of cultural heritage as a commodifications's product. In A. Kavoura et al. (Eds.), Strategic Innovative Marketing and Tourism. 8th ICSIMAT, Northern Aegean, Greece, 2019 (pp. 265-272). Springer.

Mezquita-Catedral de Córdoba (2020). COVID-19. Información general. https://mezquitacatedraldecordoba.es/covid-19/informacion-general/

Milano C., Novelli M., \& Cheer J. M. (2019). Overtourism and tourismphobia: A journey through four decades of tourism development, planning and local concerns. Tourism Planning \& Development, 16(4), 353-357. https://doi.org/10.1080/21568316.2019.1599604

Montanari, A. (2020). Covid-19 as an opportunity to tackle the phenomenon of overtourism in European historic centre: The case of Rome. Supplementi, 11, 285305. https://doi.org/10.13138/2039-2362/2542

Morgan, M., \& Dong, X. (2008). Measuring passenger satisfaction of interpretive programming on two Amtrak trains in the Midwest: Testing the expectancy disconfirmation theory. Journal of Interpretation Research, 13(2). https://doi.org/10.1177/109258720801300204

Murray, I., \& Cañada, E. (2020). La singularidad cultural como causa de la expansión del COVID-19 en España: una respuesta. AGE. https://www.age-geografia.es/site/wpcontent/uploads/2020/04/murray-ernest-v1.pdf

O'Callaghan-Gordo, C., \& Antó, J. M. (2020). COVID-19: The disease of the Anthropocene. Environmental Research, 187, 109683. https://doi.org/10.1016/j.envres.2020.109683

O’Reilly, A.M. (1986). Tourism carrying capacity: Concept and issues. Tourism Management, 7(4), 254-258. https://doi.org/10.1016/0261-5177(86)90035-x

Olcina Cantos, J. (2019). Cambio climático y actividad turística: dos procesos que se retroalimentan. In E. Cañada \& I. Murray (Eds.), Turistificación global. Perspectivas críticas en turismo (pp. 443-462). Icaria.

Olcina Cantos, J. (2020). Pandemia, cambio climático y turismo: acciones para lo inmediato y lo próximo. In M. Simancas, R. Hernández, \& N. Padrón (Coords.), Turismo pos-COVID-19. 
Reflexiones, retos y oportunidades (pp. 31-44). Cátedra de Turismo Cajacanarias-Ashotel de la Universidad de la Laguna.

Opačić, V.T. (2019). Tourism valorisation of cultural heritage. In M. Obad Šćitaroci, B. B. Obad Šćitaroci \& A. Mrđa (Eds.), Cultural Urban Heritage. Development, Learning and Landscape Strategies (pp. 181-196). Springer.

Opera della Primaziale Pisana (2020). Website. https://www.opapisa.it/en

Organisation for Economic Co-operation and Development (OECD) (2009). The Impact of Culture on Tourism. OECD Publications.

Packer, J., \& Ballantyne, R. (2016). Conceptualizing the visitor experience: A review of literature and development of a multifaceted model. Visitor Studies, 19(2), 128143. https://doi.org/10.1080/10645578.2016.1144023

Papathanassis, A. (2017). Over-tourism and anti-tourist sentiment: An exploratory analysis and discussion. "Ovidius" University Annals, Economic Sciences Series, XVII(2), 288293. https://ideas.repec.org/a/ovi/oviste/vxviiy2017i2p288-293.html

Pascoal, S., Tallone, L., \& Furtado, M. (2020). The impact of COVID-19 on cultural tourism: Virtual exhibitions, technology and innovation. In A. Abreu et al. (Eds,), Advances in Tourism, Technology and Systems. ICOTTS 2020. Smart Innovation, Systems and Technologies. Springer. https://doi.org/10.1007/978-981-33-4260-6_16

Pepe, A., \& Percoco, A. (2020). Quel che resta della legacy di Matera 2019 dopo il Covid-19. Documenti Geografici, 1, 593-603. https://doi.org/10.19246/DOCUGEO2281$\underline{7549 / 20200137}$

Pimentel de Oliveira, D. (2020). Tarjeta turística Safety and Security: el pasaporte para turistas y destinos seguros. Cuadernos de Turismo, 46, 489504. https://doi.org/10.6018/turismo.451931

Ponsignon, F., \& Derbaix, M. (2020). The impact of interactive technologies on the social experience: An empirical study in a cultural tourism context. Tourism Management Perspectives, 35, 100723. https://doi.org/10.1016/j.tmp.2020.100723

Prebensen, N. K., Chen, J. S., \& Uysal, M. (2014). Creating Experience Value in Tourism. CABI. 
Prideaux, B., Thompson, M., \& Pabel, A. (2020). Lessons from COVID-19 can prepare global tourism for the economic transformation needed to combat climate change. Tourism Geographies, 22(3), 667/678. https://doi.org/10.1080/14616688.2020.1762117

Priority Actions Programme, \& Regional Activity Center (PAP/RAC) (1997). Guidelines for Carrying Capacity Assessment for Tourism in Mediterranean Coastal Areas. https://www.papthecoastcentre.org/pdfs/Guidelines\%20CCA\%20Tourism.pdf

Pybus, C. (2019). New tools for cultural heritage tourism: Accessible virtual reality for Milan's basilica Sant'Ambrogio. GEORES 2019 - 2nd International Conference of Geomatic and Restoration. https://doi.org/10.5194/isprs-archives-XLII-2-W11-1003-2019

Reisinger, Y. (1994). Tourist-Host contact as a part of cultural tourism. World Leisure \& Recreation, 36(2), 24/28. https://doi.org/10.1080/10261133.1994.9673910

Reuschke, D., \& Felstead, A. (2020). Changing workplace geographies in the COVID-19 crises. Dialogues in Human Geography, 208212. https://doi.org/10.1177/2043820620934249

Riaño, P. H. (2020a, October 20). Los museos buscan rentabilizar su presencia en la red. El País (p. 27).

Riaño, P. H. (2020b, 13 de diciembre). Por un puñado de turistas. El País. https://elpais.com/espana/madrid/2020-12-13/por-un-punado-de-turistas.html

Richards, G. (2005). European Cultural Tourism: Trends and prospects. In G. Richards (Ed.), Cultural Tourism in Europe (pp. 225-241). Association for Tourism and Leisure Education. http://www.tram-research.com/cultural_tourism_in_europe.pdf

Richards, G. (2007). ATLAS Cultural Tourism Survey. Summary Report 2007. http://www.tramresearch.com/atlas/ATLAS\%20Cultural\%20Tourism\%20Survey\%202007.PDF

Richards, G. (2019). Culture and tourism: Natural partners or reluctant bedfellows? A perspective paper. Tourism Review, 75(1), 232-234. https://doi.org/10.1108/TR-04-2019-0139

Richards, G., \& Wilson, J. (2006). Developing creativity in tourist experiences: A solution to the serial reproduction of culture? Tourism Management, 27(6), 12091223. https://doi.org/10.1016/j.tourman.2005.06.002 
Ritchie, B.W. (2008). Tourism disaster planning and management: From response and recovery to reduction and readiness. Current Issues in Tourism, 17(4), 315 348. https://doi.org/10.1080/13683500802140372

Rodríguez Fino, E., Martín Gutiérrez, J., Meneses Fernández, D., \& Armas Davara, E. (2013). Interactive tourist guide: Connecting Web 2.0 augmented reality, and QR codes. Procedia Computer Science, 25, 338-344. https://doi.org/10.1016/j.procs.2013.11.040

Romero-García, L. E., Aguilar-Gallegos, N., Morales-Matamoros, O., Badillo-Piña, I., \& TejeidaPadilla, R. (2019). Urban tourism: a system approach - state of the art. Tourism Review, 74(3), 679-693. https://doi.org/10.1108/TR-06-2018-0085

Roy, A. (2017). El ministerio de la felicidad suprema (C. Ceriani, Trans.). Anagrama.

Russo, A.P. (2016). Las nuevas fronteras del estudio en turismo: retos conceptuales y epistemológicos. Revista CIDOB D'Afers Internacionals, 113, 15 -

32. https://www.cidob.org/es/articulos/revista_cidob_d_afers_internacionals/113/las_nuevas fronteras_del_estudio_del_turismo_retos_conceptuales_y_epistemologicos

Ryu, S., Gao, H., Wong, J.Y., Shiu, E.Y.C., Xiao, J., Fong, M.W., \& Cowling, B.J. (2020). Nonpharmaceutical measures for pandemic influenza in nonhealthcare settings - international travel - related measures. Emerging Infectious Diseases, 26(5), 961 966. https://doi.org/10.3201/eid2605.190993

San Román Cutanda, J.M. (2018). Evolución histórico-jurídica del marco legal de la profesión de guía turístico en España: algunos apuntes sobre el turismo en Toledo. Archivo Secreto: Revista $\begin{array}{llll}\text { Cultural de Toledo, } & \text { 7, }\end{array}$ 139. https: / / dialnet.unirioja.es/servlet/articulo?codigo=6834133\&orden=0\&info=link Santos Solla, X.M., \& Lois González, R.C. (Coords.) (2005). Desarrollo turístico sostenible en ciudades históricas. Ayuntamiento de Lugo.

Santos Veloso, A. \& dos Santos Queirós, A. (2019). The role of the tourist guide in the context of the conservation and valuation of the tangible and intangible heritage. Journal of Tourism and Heritage Research, 2(4), 308-326. http://www.jthr.es/index.php/journal/article/view/117 Sariego López, I. (2020). Los retos del turismo cultural en la ciudad de Santander para convertirse en un destino seguro pos-COVID-19. Estudios Turísticos, 219, 5970. https://dialnet.unirioja.es/servlet/articulo?codigo=7610393\&orden=0\&info=link 
Schneider, D. (1978). The Carrying Capacity Concept as a Planning Tool. American Planning Association.

Schubert, S.F., \& Schamel, G. (2020). Sustainable tourism development: A dynamic model incorporating resident spillovers. Tourism Economies. https://doi.org/10.1177/1354816620934552

Scott, D., Hall, C. M., \& Gössling, S. (2019). Global tourism vulnerability to climate change. Annals of Tourism Research, 77, 49-61. https://doi.org/10.1016/j.annals.2019.05.007

Sequera, J. (2020). Turistificación global en tiempos de COVID-19. Una reseña inusual [Review of the book Turistificación global. Perspectivas críticas en turismo, by E. Cañada \& I. Murray (Eds.)]. Boletín de la Asociación de Geógrafos Españoles, 85, 2971, 1-5. https://bage.agegeografia.es/ojs/index.php/bage/article/view/2971

Sharpley, R. (2020). Tourism, sustainable development and the theoretical divide: 20 years on. $\begin{array}{llll}\text { Journal of Sustainable } & \text { 1932- }\end{array}$ 1946. https://doi.org/10.1080/09669582.2020.1779732

Siang, F.G., Ahmad, Z.B., Aziz, K.B.A., \& Suhaifi, S.B. (2019). Augmented reality mobile application for museum: A technology acceptance study. 6th International Conference on Research and Innovation in Information Systems (ICRIIS), 16. https://doi.org/10.1109/ICRIIS48246.2019.9073457

Simancas Cruz, M., Hernández Martín, R., \& Padrón Fumero, N. (Coords.). Turismo pos-COVID19. Reflexiones, retos y oportunidades. La Laguna: Cátedra de Turismo Cajacanarias-Ashotel de la Universidad de la Laguna. https://riull.ull.es/xmlui/handle/915/20451

Sinclair, I. (2015). La ciudad de las desapariciones (J. Calvo, Trans.). Alpha Decay.

Singh, S (2020). 'Quixotic' tourism? Safety, ease, and heritage in post-COVID world tourism. Journal of Heritage Tourism. https://doi.org/10.1080/1743873X.2020.1835924

Solima, L., \& Izzo, F. (2018). QR codes in cultural heritage tourism: New communications technologies and future prospects in Naples and Warsaw. Journal of Heritage Tourism, 13(2), 115 127. https://doi.org/10.1080/1743873X.2017.1337776 
Song, L., \& Tan, S. (2012). A path analysis of the development of tourism products concerning compound-type cultural heritage. Tourism Tribune, 27, 93101. http://caod.oriprobe.com/articles/31339392/A_Path_Analysis_of_the_Development_of_T ourism_Products_Concerning_Comp.htm

Sönmez, S., Wiitala, J., \& Apostolopoulos, Y. (2019). How complex travel, tourism, and transportation networks influence infectious disease movement in a borderless world. In D.J. Timothy (Ed.), Handbook of Globalisation and Tourism (pp. 27-43). Edward Elgar.

Stecker, B., \& Hartmann, R. (2019). Case study: Balancing the sustainability of tourism in city destinations-The case of Dubrovnik. In D. Lund-Durlacher et al. (Eds.), Corporate Sustainability and Responsibility in Tourism (pp. 373-382). Springer.

Stovall, W., Higham, J., \& Stephenson, J. (2019). Prepared for take-off? Anthropogenic climate change and the global challenge of twenty-first-century tourism. In D. J. Timothy (Ed.), Handbook of Globalisation and Tourism (pp. 188-197). Edward Elgar.

Swanson, K.K., \& Timothy, D.J. (2012). Souvenirs: icons of meaning, commercialization and commoditization. Tourism Management, 33(3),

489-

499. https://doi.org/10.1016/j.tourman.2011.10.007

Świąder, M. (2018). The implementation of the concept of environmental carrying capacity into spatial management of cities: A review. Management of Environmental Quality, 29(6), 10591074. https://doi.org/10.1108/MEQ-03-2018-0049

Teruel Serrano, M.D. (2016). Eficiencia comunicativa de las páginas web en el caso de la gestión turística de los sitios Patrimonio de la Humanidad en España. Boletín de la Asociación de Geógrafos Españoles, 71, 323-346. https://doi.org/10.21138/bage.2285

Thomson, G., \& Newman, P. (2018). Cities and the Anthropocene: Urban governance for the new era of regenerative cities. Urban Studies, 57(7), 1502 1519. https://doi.org/10.1177/0042098018779769

Thurot, J.M. (1980). Capacité de charge et production touristique. Université d'Aix-Marseille.

Timothy, D.J. (2011). Cultural Heritage and Tourism: An Introduction. Channel View.

Timothy, D.J., \& Boyd, S.W. (2006). Heritage Tourism in the $21^{\text {st }}$ Century: Valued traditions and new perspectives. Journal of Heritage Tourism, 1(1), 1 16. https://doi.org/10.1080/17438730608668462 
tom Dieck, M.C., \& Jung, T. (2018). A theoretical model of mobile augmented reality acceptance in urban heritage tourism. Currents Issues in Tourism, 21(2), 154174. https://doi.org/10.1080/13683500.2015.1070801

Tripadvisor (2020, July 24). La Última Cena. https://www.tripadvisor.es/Attraction_Reviewg187849-d314197-Reviews-II_Cenacolo-Milan_Lombardy.html

Troitiño Torralba, L. (2012). Las ciudades patrimonio de la humanidad de la región turística de Madrid: niveles medios de funcionalidad y adecuación turística del patrimonio cultural. Papers, 51, 109-131. http://www. papersdeturisme.gva.es/ojs/index.php/Papers/article/view/199

Troitiño Vinuesa, M.A., \& Troitiño Torralba, L. (2010). Patrimonio y turismo: una complementariedad necesaria en un contexto de uso responsable del patrimonio y cualificación de la visita. Revista Patrimonio Cultural de España, 3, 89-108.

Tsai, S.P. (2019). Augmented reality enhancing place satisfaction for heritage tourism marketing.

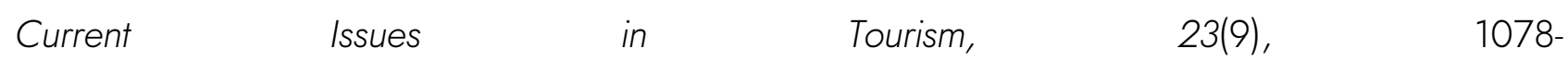
1083. https://doi.org/10.1080/13683500.2019.1598950

UNESCO (2016). Culture: Urban Future. Global Report for on Culture for Sustainable Urban Development. https://unesdoc.unesco.org/ark:/48223/pf0000245999

UNWTO (2015). Affiliate Members Global Reports, Volume Twelve-Cultural Routes and Itineraries. UNWTO. https://www.e-unwto.org/doi/book/10.18111/9789284417704

UNWTO (2020a). Barómetro OMT del Turismo Mundial. UNWTO. https://www.eunwto.org/doi/abs/10.18111/wtobarometeresp.2020.18.1.1

UNWTO (2020b, April 14). COVID-19: anteponiendo a las personas. UNWTO. https://www. unwto.org/es/turismo-covid-19

Vareiro, L., Ribeiro, J. C., \& Remoaldo, P. C. (2018). What influences a tourist to return to a cultural destination? International Journal of Tourism Research, 21(2), 280290. https://doi.org/10.1002/jtr.2260

Velasco González, M., Herrero López, R., \& López Sánchez, E. (2019). El orden del caos: la decisión del gobierno ante el problema del impacto del turismo en el centro urbano de Madrid. Boletín de la Asociación de Geógrafos Españoles, 83, 2832, 1 42. http://dx.doi.org/10.21138/bage.2832 
Veríssimo, M., Moraes, M., Breda, Z., Guizi, A., \& Costa, C. (2020). Overtourism and tourismphobia: A systematic literature review. Tourism: An International Interdisciplinary Journal, 68(2), 156-169. https://doi.org/10.37741/t.68.2.4

Vicente, A. (2020, June 25). El Louvre seguirá fiel al turismo. El País (p. 28).

Vilar, M. A. (2020, July 1). Reabren desde hoy atractivos turísticos como el pórtico o la cueva del Rei Cintolo. La Voz de Galicia (p. 8).

Wall, G. (1997). Tourism attractions: Points, lines and areas. Annals of Tourism Research, 24(1), 240-243. https://doi.org/10.1016/S0160-7383(96)00039-4

Wall, G. (2020). From carrying capacity to overtourism: a perspective article. Tourism Review, 75(1), 212-215. https://doi.org/10.1108/TR-08-2019-0356

Wang, D., Xiang, Z, \& Fesenmaier (2014). Smartphone use in everyday life and travel. Journal of Travel Research, 55(1), 52-63. https://doi.org/10.1177/0047287514535847

William, P. W., \& Gill, A. (1995). Tourism carrying capacity management issues. In W. F. Theobald (Ed.), Global Tourism: The Next Decade (pp. 174-187). Butterworth-Heinemann.

Xia, J., Evans, F. H., Spilsbury, K., Ciesielski, V., Arrowsmith, C., \& Wright, G. (2010). Market segments based on the dominant movement patterns of tourists. Tourism Management, 31(4), 464-469. https://doi.org/10.1016/j.tourman.2009.04.013

Yamashita, S. (2016). Cultural Tourism. In Encyclopedia of Tourism (pp. 212-224). Springer.

Yescas Sánchez, M. (2018). La turistificación en el Centro Histórico de Oaxaca. Estudios Críticos del Desarrollo, VIII(14), 75-111.

https://estudiosdeldesarrollo.mx/estudioscriticosdeldesarrollo/wp-

content/uploads/2019/01/ECD14-3.pdf

Zazo Moratalla, A., \& Álvarez Agea, A. (2020). Ciudad COVID 19: una nueva inequidad en el espacio y tiempo urbano. Urbano, 41, 4-9.

https://doi.org/10.22320/07183607.2020.23.41.00

Zhang, H. Q., \& Chow, I. (2004). Application of importance-performance model in tour guides' performance: Evidence from mainland Chinese outbound visitors in Hong Kong. Tourism Management, 25(1), 81-91. https://doi.org/10.1016/S0261-5177(03)00064-5 
Zhang, X., Zhou, L., Wu, Y., Skitmore, M., \& Deng, Z. (2015). Resolving the conflicts of sustainable world heritage landscapes in cities: fully open or limited access for visitors? Habitat International, 46(91), 91-100. https://doi.org/10.1016/i.habitatint.2014.11.004

Zhang, Y., Lee, T. J., \& Xiong, Y. (2018). A conflict resolution model for sustainable heritage tourism. International Journal of Tourism Research, 21(4), 478492. https://doi.org/10.1002/jtr.2276

Zusman, P.; Bietti, G. L., \& Landini, G. (2020). Las múltiples implicaciones espaciales de la difusión del COVID-19. Un estado de la cuestión. Punto Sur, 3, 234262. https://doi.org/10.34096/ps.n3.9707 